\title{
Gambling With the Bronx Bombers: Betting On, Against, And WITH THE YANKEES
}

\author{
Ronald J. Rychlak*
}

The New York Yankees, arguably the most hallowed name in all of professional sports, has probably had more money wagered on the outcome of its games than any other team in any sport. ${ }^{1}$ Although few people today may be aware of it, the team itself has a long history of association with gamblers and gambling. The first owners of the Yankees were notorious gamblers; the team's first captain was indicted in the 1919 "Black Sox" scandal; one Yankees' pitcher was suspected of having thrown another Series game; one owner had ties to underworld figures in Las Vegas; another owner was suspended for his dealings with a known gambler; and one of the most beloved Yankees of all time was barred from baseball due to his association with a casino. ${ }^{2}$ Additionally, it has been suggested that the Yankees' threat of moving to New Jersey in the mid-1990s was linked to New York State authorizing gambling. ${ }^{3}$

\section{Early Innings: Gambling on a New League}

The relationship between the Yankees and gambling, which continues today, began even before the first Yankee players took the field. ${ }^{4}$ In the 1800 s, people thought of baseball in the same way people today might think of horse racing or jai alai - gambling was simply part of the sport. Brooklyn's Union Grounds was considered the finest ballpark of the 1870s. One reason was because it had a special facility inside the stadium for the use of bookmakers

* B.A. Wabash College, 1980; J.D. Vanderbilt University, 1983. Ronald J. Rychlak is the Mississippi Defense Lawyers Association Professor of Law at the University of Mississippi. $\mathrm{He}$ is a member of the International Masters of Gaming Law, on the editorial board of The Gaming Law Review, and serves as the university's Faculty Athletic Representative.

1 See generally Report: Standard Bet \$2,000, Tulsa World, June 27, 1989, http:// www.tulsaworld.com/news/article.aspx?no=subj\&articleid=43459 (discussing how Pete Rose reportedly won more money betting on the Yankees than on any other team); see generally Ronald J. Rychlak, Pete Rose, Bart Giamatti, and the Dowd Report, 68 Miss. L.J. 889 (1999) (discussing Rose's gambling problems).

2 See Mickey Mantle \& Herb Gluck, The Mick 252 (1986). In 1983, Mickey Mantle signed a $\$ 100,000$ a year contract to work at the Claridge Hotel in Atlantic City. Willie Mays worked in a similar position at Bally's Park Place in Atlantic City, right across the street. Bowie Kuhn effectively banned them both from baseball because of their association with casinos. Id.

${ }^{3}$ Marianne T. Caulfield, Will It Take a Move by the New York Yankees for the Seneca Nation to Obtain a Class III Gaming License?, 44 CAtH. U. L. Rev. 279, 279 (1994).

4 See Glenn Stout, Top of the Heap: A Yankees Collection 13 (2003). 
and a section of the grandstands reserved for betting spectators. ${ }^{5}$ As one author wrote, "Few nineteenth-century sports fans would have thought it possible to separate sports from gambling, even if it had occurred to them that it might be a good idea to do so." 6

Early baseball leagues were so loosely structured that there was little control over players. ${ }^{7}$ As stories of bribery, drunken players, and thrown games spread to the public, confidence in the game's integrity plummeted. In 1876, Chicago businessman William A. Hulbert decided that it was time to create a new league, the National League of Professional Baseball Clubs or simply, the National League ("NL"). ${ }^{8} \mathrm{He}$ announced three objectives: "first - to encourage, foster and elevate the game of base ball [sic]; second - to enact and enforce proper rules for the exhibition and conduct of the game; and third - to make base ball [sic] playing respectable and honorable."9

In 1877, the new league's tolerance for gambling scandals was severely tested. Word spread that gamblers from New York were paying Louisville players to throw the pennant. ${ }^{10}$ When four players confessed, the league held firm, banning all four players from the NL. ${ }^{11}$ That did not, however, mean that they were finished with baseball. The St. Louis team (the Brown Stockings) signed the guilty players and dropped out of the NL (along with teams from Louisville and Hartford) to join the American Association. ${ }^{12}$ The loose rules in the American Association caused some writers of the day to nickname it the "Beer and Whisky league." 13

Open drinking, gambling, and rumors of thrown games persisted throughout the late 1800s. ${ }^{14}$ The NL continued to work on its image. It banned open gambling and the sale of alcohol at all of its parks. ${ }^{15}$ It also expelled the Cin-

5 See Daniel E. Ginsburg, The Fix Is in: A History of Baseball Gambling and Game FIXING SCANDAls 17 (1995). The betting was so bad that one section of the park was known as the Gold Board, with activity that rivaled that of the New York Stock Exchange. Id.

6 Thomas Gilbert, Superstars \& Monopoly Wars: Nineteenth-Century Major League Baseball 10 (1995).

7 See Derek Zumsteg, The Cheater's Guide to Baseball 171-81 (2007); see Ginsburg, supra note 5, at 17. According to Lee Allen, one of baseball's premier historians, "[T]he players travelled from city to city like princes, sporting diamonds, drinking champagne at dinner every night, and ostentatiously paying the tab by peeling off folding money from wads of the stuff that mysteriously reproduced themselves." $I d$.

8 John G. Robertson, Baseball's Greatest Controversies: Rhubarbs, Hoaxes, Blown Calls, Ruthian Myths, Managers' Miscues, and Front-Office Flops 11 (1995).

9 Gilbert, supra note 6, at 27.

10 GinsBurg, supra note 5, at 46. Suspicions of throwing games were aroused when Louisville club president Charles E. Chase got an anonymous telegram telling him to "watch your men!"' Id.

11 Id. at 49.

12 See generally David Nemec, The Beer and Whisky League: The Illustrated History of the American Association-Baseball's Renegade Major League (2004) [hereinafter "Nemec, Beer and Whiskey League"]; see generally John David CASH, BEFORE They Were Cardinals: Major League Baseball in Nineteenth-Century St. Louis (2002).

13 Robertson, supra note 8, at 12.

14 See generally GINSBURG, supra note 5, at 54-68.

$15 \mathrm{Id}$. at 57. 
cinnati team in 1880 for violating league rules. ${ }^{16}$ Nevertheless, with numerous leagues and lax enforcement, baseball did not have the wholesome image that it would later cultivate.

In 1900, Ban Johnson renamed his minor league organization (the Western League) as the American League ("AL") and he claimed major league status in 1901. ${ }^{17}$ One of his announced purposes of the league was to clean up baseball's image. ${ }^{18}$ Among other things, he wanted to rid the sport of gambling, so he prohibited betting in all AL ballparks. ${ }^{19}$

Johnson had difficulty getting the AL off the ground primarily because he was unable to place a team in New York City. ${ }^{20}$ In making the AL a major league, Johnson ignored the reserve clause in NL contracts, and offered higher salaries to attract star players. ${ }^{21}$ This touched off a war between the AL and the NL. Consequently, Andrew Freedman, the owner of the NL's New York franchise (the Giants), used his connections with the city leaders in Tammany Hall to block Johnson from getting a site for his stadium. ${ }^{22}$ Thus, while Johnson was able to place AL teams in other NL venues-including Boston, Chicago, Philadelphia, and St. Louis-Freedman kept him out of New York for two seasons. ${ }^{23}$ As both men knew, without a New York team, the AL would never be considered a true major league. ${ }^{24}$

By 1903, Johnson was determined to get into the Big Apple. One of his old friends put him in touch with Frank J. Farrell and Williams S. "Big Bill" Devery, who had sufficient clout at Tammany Hall to overcome Freedman's blockade. ${ }^{25}$ Farrell and Devery also had enough cash to give the New York AL team a good chance of survival. With two years of waiting under his belt, Johnson, "the sworn foe of every kind of baseball crooks and of gambling on base-

16 Dennis Purdy, The Team-By-Team Encyclopedia Of Major League Baseball 260 (2006) (explaining how the Cincinnati organization refused to ban alcohol sales and stop Sunday play, resulting in their ejection from the league).

17 Robertson, supra note 8, at 13.

18 See GinsBurg, supra note 5, at 70 .

19 Id.

20 Steven A. Riess, Touching Base: Professional Baseball and American Culture in the Progressive Era 108 (1999).

21 See Gilbert, supra note 6, at 56-60 (discussing how the reserve clause gave owners substantial control over players' careers by effectively limiting their options with regard to where they could play and since all of the NL owners agreed not to engage in a bidding war for players' services, this had the effect of driving down player salaries).

22 David Nemec, The Baseball Chronicle 12 (2001) (Tammany Hall was the Democratic Party political machine that largely controlled New York City politics at that time.) [hereinafter "Nemec, Baseball Chronicle"]; see generally Alfred Connable \& Edward Silberfarb, Tigers of Tammany: Nine Men Who Ran New York (1967).

23 Maura Flood, Up from Baltimore, in Courting the Yankees: Legal Essays on the BRONX Bombers 261, 267 (2003).

24 Id. Cecilia Tan, The 50 Greatest Yankee Games 5 (2005).

25 See Nemec, Baseball Chronicle, supra note 22, at 20. 
ball," ${ }^{26}$ modified his standards and entrusted the New York franchise (relocated from Baltimore) to Farrell and Devery. ${ }^{27}$

In the early 1900s, New York was the nexus of the worlds of finance, art, journalism, and politics. Gambling "flourished, unimpeded, in every quarter of the city." ${ }^{28}$ Highrollers, hustlers, pikers, con men, gangsters, and tycoons mingled in the city's illegal casinos. During the summer, those same gamblers could be found at the racetrack, betting on horses and playing cards, dice, or pool. ${ }^{29}$ Given this environment, it is not surprising that the first owners of the Yankees were gamblers. It is, however, quite amazing that crusader Johnson turned his most important team over to two characters so notoriously involved with illegal gambling: Farrell and Devery.

Farrell was a big-time racketeer and the owner of a racing stable. ${ }^{30} \mathrm{His}$ luxurious "House with the Bronze Door" at 33 West Thirty-Third Street was one of Manhattan's best-known gambling establishments. ${ }^{31}$ It was famous for its class and quiet decorum. The Bronze Door served patrons fine cigars, French wines, aged liquors, and an elaborate dinner buffet. ${ }^{32}$ While no money was accepted for refreshments, much was wagered at the gaming tables. ${ }^{33}$ Farrell's establishment was largely immune from police raids thanks to his friendship with "Big Bill" Devery, the former New York City chief of police. ${ }^{34}$

Devery was widely regarded as the most corrupt public official in New York City. Before being named police chief, he was repeatedly castigated by his superiors for taking bribes from gambling operators. ${ }^{35}$ His standard reply to investigative questioning was: "Touchin' on and appertainin' to that matter, I disremember." 36 Devery's tenure as chief of police was so bad that the state legislature decided to abolish his position and replace it with a commission system. ${ }^{37}$ Tammany Hall, however, thwarted the legislature. ${ }^{38}$ Appointed as Deputy Police Commissioner by Mayor Van Wyck, Devery was given even greater powers than before. ${ }^{39}$ After that, Devery unsuccessfully ran for mayor

26 Martin Donell Kohout, Hal Chase: The Defiant Life and Turbulent Times of Baseball's Biggest Crook 25 (2001) (quoting Fred Lieb, The Baseball Story 159 (1950)).

27 Id. (discussing Johnson saw control of the AL New York franchise go to Farrell, a notorious gambler, and Devery, who had a reputation as a corrupt police official in New York).

28 Id. at 27.

29 See e.g., Ginsburg, supra note 5, at 84.

30 Kohout, supra note 26, at 25.

31 Id.

$32 I d$. at 29.

33 Id.

34 Id. at 25.

35 Neil J. Sullivan, The Diamond in the Bronx: Yankee Stadium and the Politics of New York 16 (2001); see William Bryk, The Last Police Chief, http://www.mapsites.net/ gotham/sec6/Devery.html (last visited Dec. 27, 2011) (stating that Devery "was either an 'illiterate ruffian' or an amazing, openly corrupt, and utterly likable eccentric").

36 Sullivan, supra note 35 , at 16.

37 Bryk, supra note 35.

38 Id.

$39 I d$. 
of New York City. ${ }^{40}$ His campaign speeches were best known for the free beer that was usually served. ${ }^{41}$

Perhaps most important to Yankee fans today, however, is that Devery is the reason their team has the most recognizable symbol in sports. Louis B. Tiffany designed the now-famous interlocking "NY" insignia in 1877 for a medal that was to be given to the first NYC policeman shot in the line of duty. The team adopted the design for its uniform and caps in 1909 because coowner Devery was a former NYC police chief. ${ }^{42}$

It appears that Farrell and Devery were able to outmaneuver Freedman because they were even more corrupt than he was. ${ }^{43}$ Johnson sold them the Baltimore franchise, shifted it to New York, and announced that the president of the club was Joseph W. Gordon. ${ }^{44}$ However, Gordon, a respectable coal merchant and Tammany stalwart, was just a figurehead. After the 1903 season, he disappeared from the organization and Farrell became the president, in title, and in fact. ${ }^{45}$

Farrell and Devery built a stadium for their new team and named it Hilltop Park. ${ }^{46}$ The team became known as the Highlanders (and sometimes the Hilltoppers) because the stadium was located on the highest point of land in northern Manhattan. ${ }^{47}$ Newspapers, however, found the name too long for headlines and began calling them the Yanks or the Yankees, which the team formally adopted in $1913 .{ }^{48}$

In 1903, the Highlanders finished in fourth place, seventeen games behind Boston. ${ }^{49}$ In 1904, they improved to second place, only one and a half games behind Boston, ${ }^{50}$ but Farrell and Devery were not satisfied. They wanted a star player who could help them beat Boston and attract fans away from their intown rivals, the New York Giants. They found their man in a smooth-fielding first baseman who was an above-average hitter and an incorrigible gambler: Hal Chase.

40 Sullivan, supra note 35 , at 16.

41 Id.

42 Uniforms \& Logos, N.Y. YANKEES, http://newyork.yankees.mlb.com//nyy/history/ uniforms_logos.jsp (last visited Sep. 28, 2012).

43 Vincent Luisi, Postcards of America: New York Yankees, The First 25 Years 11 (2009).

44 Kohout, supra note 26, at 25.

45 Id. at 30.

46 Sullivan, supra note 35 , at 17.

47 Id.

48 See id. at 18; KL Snow, Hal Chase: Prince Hal, Baseball Almanac, http://www. baseball-almanac.com/articles/halchase.shtml (last visited Oct. 31, 2011); see e.g., Barry Popik, Entry from July 05, 2004, Big ApPle (Jul. 5, 2004), http://www.barrypopik.com/ index.php/new_york_city/entry/yankees_american_league_baseball_team/ ("But the New York "Yankees" are the responsibility of the legendary newspaper publisher William Randolph Hearst.").

491903 Regular Season Standings, MLB.com, http://mlb.mlb.com/mlb/standings/index .jsp?tcid=mm_mlb_standings\#19030929 (last visited Oct. 31, 2011).

50 Sullivan, supra note 35, at 17. 


\section{Prince Hal: A Royal Gambler}

Farrell and Devery's first star player was Harold "Prince Hal" Chase. He served as the first team captain for the Yankees, and he even managed the team for one full and one partial season. ${ }^{51}$ His career numbers show him to be a Hall of Fame caliber performer, but gambling-related scandals attached to his name have kept him out of the Hall of Fame. ${ }^{52}$ As his biography is aptly subtitled, Prince Hal probably was "baseball's biggest crook." 53

Chase was born on February 13, 1883, in Los Gatos, California. ${ }^{54} \mathrm{He}$ started playing baseball while attending Santa Clara University. ${ }^{55} \mathrm{He}$ supplemented his college experience (and his income) by playing semi-professional baseball in the summers. ${ }^{56}$ During a game in early 1904, Chase caught the attention of Jim Morley, president and owner of the Los Angeles club in the Pacific Coast League. ${ }^{57}$ That month, Chase left Santa Clara and signed a contract with the Los Angeles club. ${ }^{58}$ "By March 30, 1904, the Los Angeles Times wrote, 'Chase has a future before him that any ball player might look forward to. He plays first base as well as anyone would care to see." "59

Chase was a young, handsome good hitter. He was also one of the best fielding first baseman ever. ${ }^{60} \mathrm{He}$ routinely fielded bunts on the third base side of the pitcher's mound. It was said that he could field a squeeze bunt and tag out both the batter and the runner from third. ${ }^{61}$ Once, he even caught a throw from the shortstop with his shoe! The Highlanders signed him away from L.A. following the 1904 season. $^{62}$ The L.A. owner claimed that Chase's signing with New York was illegal and took the matter to court, but he could not prevent Chase from leaving. ${ }^{63}$

Before Chase made it to the big leagues, first basemen played on the bag. He was the first to move off the bag in order to cover more ground. ${ }^{64} \mathrm{He}$ also developed the now-common practices of charging bunts and moving into the outfield to retrieve cutoff throws. ${ }^{65}$ In his first year in the big leagues (1905),

51 Ginsburg, supra note 5, at 88; Kohout, supra note 26, at 70.

52 See Ginsburg, supra note 5, at 98-99.

53 Kohout, supra note 26, at title page; see also Don Dewey \& Nick Ococella, The Black Prince of Baseball: Hal Chase and Mythology of the Game (2004).

54 Ginsburg, supra note 5, at 86.

$55 I d$.

$56 I d$.

57 Id.

$58 I d$.

$59 I d$.

60 Shortly after Chase's death, sportswriter Joe Williams called Chase "the most talented baseball player California ever produced." This is strong praise, considering Ted Williams and Joe DiMaggio were native Californians in the prime of their careers. See id. at 99.

61 See Mark Gallagher, The Yankee Encyclopedia 46 (Susan M. McKinney ed., 6th ed. 2003).

62 GinsBurg, supra note 5, at 86.

${ }^{63} \mathrm{Id}$.

${ }^{64} I d$.

$65 I d$. 
he set the record for most fielding chances in a double header with thirtyeight. ${ }^{66}$ In his final season (1919), he set the NL record with thirty-five. ${ }^{67}$

From the very beginning, Chase's performance with the glove dazzled all who saw him. Baseball writer Bill James has written: "No other player in baseball history was so richly praised for his defensive skill - no one. His brilliance with the glove is easier to document than Ty Cobb's temper, Hack Wilson's drinking, or Walter Johnson's fastball; it is all over the literature of the sport." " Chase did not, however, hit very well in his first year, and the team came in sixth place with a record of 71-78. ${ }^{69}$ He turned that around in his second year (1906), finishing third in the American League batting race with a .323 average and helping the team to a solid second place finish (90-61). ${ }^{70}$ Chase's performance that year solidified his position as a star. The following January, Sporting Life called him "perhaps the biggest drawing card in baseball.",71

To the baseball fans of the era, Chase was one of the most exciting players in the league. Babe Ruth, who played with and against Lou Gehrig, Jimmie Foxx, and George Sisler, named Chase as his "all time" first baseman; Ty Cobb thought so, too. ${ }^{72}$ Clark Griffith called him the "most graceful" player he had ever seen, and Grantland Rice put Chase on his team of all-time "smart players." "73 The tenth edition of The Baseball Encyclopedia (1996) ${ }^{74}$ still lists him among the top ten first basemen of all time in chances per game (reflecting the great range for which he was known) and the top fifteen first basemen in putouts per game. ${ }^{75}$ Unfortunately, it seems indisputable that he gambled on baseball and was not reluctant to throw games to help win a bet. As talented as he was, Chase led AL first basemen in errors year after year.

On the team, Chase earned a reputation as a petty crook, a card-shark, and a cheat. ${ }^{76}$ Former Yankee teammate Ray Fisher gave this description of him during poker games among the players: "[I]f he wasn't playing, he'd sit right down next to you and see what you needed and he'd be trying to hand you the

66 Kohout, supra note 26, at 40; Mark Gallagher, supra note 61, at 47; The Sporting News, Complete Baseball Record Book 89 (2000).

67 Id.

68 Snow, supra note 48 (quoting Bill James).

69 Ginsburg, supra note 5, at 86; The Baseball Encyclopedia: The Complete and Definite Record of Major League Baseball 256 (10th ed. 1996).

70 Ginsburg, supra note 5, at 86. The Baseball Encyclopedia, supra note 69, at 259, 880. The 1906 season also saw the Highlanders once win five consecutive double headers, going 10-0 over the course of five very busy days. New York Yankees, SpORTs EnCYClopeDIA, http://www.sportsencyclopedia.com/al/nyyanks/yankees.html (last visited Feb. 13, 2012).

71 Ginsburg, supra note 5, at 86.

72 Id. at 98-99.

73 Gallagher, supra note 61, at 46.

74 The Baseball EnCyClopedia, supra note 69, at 53.

75 Id. "Chances per game," reflects how often a defensive player touches the ball in a fielding situation, and "putouts per game" indicates how often a fielder tags a runner (or the base) to record an out. A high number of chances or putouts indicates that the fielder gets many batted or thrown balls, suggesting good range in the field.

76 Koноuт, supra note 26 , at 195 . He was said to be "addicted" to stealing cigars and other small items. Id. at 47. 
cards so you would cheat. Good fellow, but just wanted to do things that weren't right." 77 While teammates seemed to enjoy playing cards with Chase, one bet caused some tension between him and his teammates early in his career. In 1906, team owner Frank Farrell had a racehorse named after the New York manager, Clark Griffith. The horse was entered in the Withers Stakes at Belmont, and Chase was sure he would win. Prince Hal convinced a number of his teammates to bet their spare money on the horse. ${ }^{78}$ It finished third, several lengths back.

In 1908, Kid Elberfeld replaced Griffith as manager. ${ }^{79}$ This did not please Chase, who wanted the job for himself. ${ }^{80}$ Rumors soon circulated that Chase was not playing to the best of his ability, perhaps to sabotage Elberfeld's position with the team. ${ }^{81}$ It partially worked. Elberfeld was fired in 1909, but Chase did not get the job. ${ }^{82}$ George Stallings, a strict disciplinarian, replaced Elberfeld. ${ }^{83}$ The club improved under his leadership, moving from last place in 1908 , to second place in 1910, but Chase was still not happy. By late September, things had fallen apart and Stallings publicly charged Chase with throwing games. ${ }^{84}$

Club president Frank Farrell, who had no aversion to taking or placing bets, met with Stallings to hear the charges against the team's star player. ${ }^{85}$ After the meeting, Farrell (supported by AL President Ban Johnson) exonerated Chase, saying, "Stallings has utterly failed in his accusations against Chase." 86 A few days later, Farrell fired Stallings and named Chase as his replacement. ${ }^{87}$

Chase got a good start as manager of the Yankees, winning ten of the team's season's final fourteen games in $1910 .{ }^{88}$ In 1911, however, Chase's only full year as skipper, the Highlanders dropped from second place, with a record of 88-63, to sixth place, with a record of 76-76. ${ }^{89}$ Harry Wolverton replaced Chase at the end of the season. ${ }^{90}$ Chase kept playing, but he never managed again. ${ }^{91}$

Rumors continued that Chase was "not playing up to his abilities" during the 1912 season, when future Hall of Famer and legendary manager, Frank

77 Id. at 195.

$78 I d$. at 43.

79 Ginsburg, supra note 5, at 87.

$80 \mathrm{Id}$.

${ }^{81} \mathrm{Id}$.

$82 \mathrm{Id}$.

${ }^{83}$ Id. The relationship between Stallings and Chase was a particularly tense one, as Chase made no secret of the fact that he coveted the managerial position. Id.

${ }^{84} I d$. A source of the dissension between the two men was Chase's throwing of games. The fact that he had learned how to do so very subtly caused a rift between Farrell and Stallings as well. See id. at 87-88.

85 Id. at $87-88$.

86 Id. at 88 .

87 Id.

${ }^{88} I d$.

89 Id. at $87-88$.

$90 \mathrm{Id}$. at 88.

91 Id. at 88. Chase's lifetime managerial record was 86-80. Id. 
Chance, (of "Tinkers to Evers to Chance" fame) ${ }^{92}$ replaced Wolverton as manager of the Yankees. ${ }^{93}$ The situation came to a head in 1913, when Chance went public with his suspicions. ${ }^{94}$ In a conversation with reporters, Chance stated, "I want to tell you fellows what's going on. Did you notice some of the balls that got away from Chase today? They weren't wild throws; they were only made to look that way. He has been doing that right along. He is throwing games on me!"95 Two days later, on May 13, 1913, the Yankees traded Chase to the Chicago White Sox for infielder Rollie Zieder and first baseman Babe Borton. ${ }^{96}$

In Chicago, Chase seemingly tried to play it straight for a while; unfortunately, this did not last. His lackadaisical play became so blatant that fans and players alike would taunt him before ball games, shouting, "What's the odds?" 97 Nevertheless, he was still such a talent that a newly formed league, the Federal League ("FL"), sought him out to help establish it as a true major league. ${ }^{98}$ On June 20, 1914, Chase gave the White Sox a ten-day notice on his contract and jumped to the FL's newly formed team in Buffalo. ${ }^{99}$

Chicago owner, Charles Comiskey, unsuccessfully sued to enjoin Chase from playing in the FL. ${ }^{100}$ After the legal proceedings, Chase joined the Buffalo club, hitting .347 during the remainder of the year and .291 in $1915 .{ }^{101} \mathrm{He}$ also knocked a league-leading seventeen home runs in $1915 .{ }^{102}$ When the FL folded after the 1915 season, the White Sox expressed no interest in Chase, and he was declared a free agent. ${ }^{103}$ Despite his talent, there was no bidding contest for his services. Finally, Cincinnati offered Chase a contract, and he signed. ${ }^{104}$

In 1916, while playing for the Cincinnati Reds, Chase led the NL with 184 hits and a career-high batting average of $.329 .{ }^{105} \mathrm{He}$ had the second highest slugging percentage in the league (.459), second most RBIs (82) and third most

92 In 1910, New York newspaper columnist Franklin Pierce Adams immortalized the trio in a verse entitled Baseball's Sad Lexicon. See "Tinker to Evers to Chance!," Library of CONGREss, http://memory.loc.gov/ammem/bbhtml/bb1.html (last visited Oct. 2, 2012).

93 Ginsburg, supra note 5, at 88 .

94 Id.

95 Id.

96 Id.

97 Robert Lusetich, White Sox Scandal Blackened Baseball, Australian, Apr. 17, 2000, at 32.

98 Ginsburg, supra note 5, at 89.

99 Id. In a virtually unprecedented move, Chase reversed the intent of a clause in his contract that allowed the club to rescind the contract with ten days' notice. Id.

100 Id. Initially, Comiskey was awarded an injunction against Chase, but the injunction could not be served because Chase fled to Canada. Days later, Chase returned to Buffalo, but was prevented from playing because the injunction was in effect. The tables turned however, when Judge Herbert Bissell overturned the injunction on the basis of its unfairness, stating that it lacked "mutuality." Id. This action was a predecessor to the action that ultimately ended in the United States Supreme Court. See Nat'l League of Prof'1 Baseball Clubs v. Fed. Baseball Club of Balt., Inc., 269 F. 681, 682 (D.C. Cir. 1920), aff'd 259 U.S. 200 (1922). 101 All of Chase's hitting records can be found in The Baseball EnCYCLOPEDIA, supra note 69 , at 880 .

102 GinsBurg, supra note 5, at 89.

103 Id.

104 Id. at 90.

105 Id. 
total bases (249). ${ }^{106}$ When rumors circulated that manager Buck Herzog was about to be let go, the press speculated that Chase was the heir apparent. Unfortunately for him, Christy Mathewson, who had a reputation as being an honest man and solid citizen, got the job. ${ }^{107}$

Mathewson and Chase seemed to have gotten along well enough in 1916 and 1917. Chase led the league in at-bats in 1917 (602), was second in RBIs (86) and was in the top ten in numerous other categories. ${ }^{108}$ By 1918, however, the relationship soured and Chase's offensive production decreased. In August, Mathewson suspended Chase without pay for "indifferent playing." 109 His error totals were not up significantly in 1918, nor was Chase's fielding percentage significantly different from previous years, but Mathewson was now the second manager to accuse him of throwing games.

Mathewson became suspicious when he saw Chase field a ground ball and toss it to the pitcher covering first base. ${ }^{110}$ Mathewson had been one of the greatest pitchers of all time, and he knew exactly how this play should be executed. Chase was an excellent fielder, but Mathewson noticed that he often made the throw just wild enough so the batter would be safe. To all appearances, when this play went wrong it was the pitcher's fault, but Mathewson knew better. He accused Chase of throwing games, and said that, if not for him, the Reds would have had a chance at the pennant. ${ }^{111}$ As it was, they finished in third place, $151 / 2$ games back. ${ }^{112}$

In January 1919, the NL president, John Heydler, held a hearing on Mathewson's charges. ${ }^{113}$ Chase's chief accusers were Mathewson, Giants pitcher William "Pol" Perritt, and Reds pitcher Jimmy Ring (who said that Chase tried

106 Id.; see also Hal Chase Career Stats, MLB.COM, http://mlb.mlb.com/team/player.jsp? player_id=112216 (last visited Oct. 2, 2012). Batting average is the total number of hits divided by the total number of at-bats. Slugging percentage is the number of total bases (e.g., singles-1, doubles-2, triples-3, home runs-4) divided by the total number of at-bats. Batting Average, Answers.COM, http://www.answers.com/topic/batting-average (last visited Oct. 2, 2012). Slugging percentage is the traditional indicator of power, as opposed to batting average, which measures hitting without power. Slugging Percentage, Answers.COM, http:// www.answers.com/topic/slugging-average (last visited Oct. 2, 2012).

107 See generally GinsBurg, supra note 5, at 90-91. Mathewson pitched for the New York Giants from 1900 until 1916 (he also threw one complete game victory for the Reds in 1916), and was one of the most respected players of his era. He regularly led the league in several pitching categories, including ERA, wins, and fewest walks. NemEC, BASEBALL Chronicle, supra note 22, at 12-13, 20; The Baseball Encyclopedia, supra note 69, at 2191-92. ERA (earned run average) is a measure of pitching effectiveness based on the number of earned runs allowed by a pitcher every nine innings. Earned Run Average Definition, BING DictionARY, http://www.bing.com/Dictionary/search?q=define+earned+run+ average \&qpvt=definition+of+earned+run+average \&FORM=DTPDIA (last visited Oct. 2, 2012).

108 Hal Chase Career Stats, supra note 106.

109 Ginsburg, supra note 5, at 90.

110 Id.

111 Id. at 90-91. Most of the evidence offered against Chase came in the form of testimony of two of his former teammates, William Perritt and Jimmy Ring. Id.

1121918 Regular Season Standings, MLB.com, http://mlb.mlb.com/mlb/standings/ index.jsp?tcid=mm_mlb_standings\#19180902 (last visited Oct. 2, 2012).

113 Ginsburg, supra note 5, at 91. 
to bribe him to throw a game). ${ }^{114}$ Giants manager, John McGraw, and Reds players, "Greasy" Neal and Mike Regan, also testified. ${ }^{115}$ The five-hour hearing took place behind closed doors. ${ }^{116}$ At the conclusion of the hearing, NL President Heydler announced his findings:

In substance the player was charged with making wagers against his club on games in which he participated. In justice to Chase, I feel bound to state that both the evidence and the records of the games to which reference was made, fully refute this accusation. In one game in which it was intimated that Chase bet against his club, the records show that in the sixth inning, with two men on bases and the score two to nothing against his team, Chase hit a home run, putting Cincinnati one run ahead.

All available evidence has been carefully taken and considered. If the charge were proved, it would follow as matter of course that the player would forever be disqualified from participating in National League games. Under such circumstances I would not hesitate to so decide, as the interests of the public and of the game of baseball are far more important than the fate of any individual. These interests it is my clear duty to protect, no matter what the effect may be on players or clubs.

Any player who during my term as President of the National League is shown to have any interest in a wager on any game played in the League, whether he bets on his club or against it, or whether he takes part in the game or not, will be promptly expelled from the National League. Betting by players will not be tolerated.

My conclusion and finding, after full consideration of the evidence, is that it is nowhere established that the accused was interested in any pool or wager that caused any game of ball to result otherwise than on its merits, and that player Hal H. Chase is not guilty of the charges brought against him. ${ }^{117}$

After the hearing, the NL lifted the team-imposed suspension of Chase, but the Reds did not want Chase back, regardless of the outcome. Interestingly, Heydler later confided that he knew Chase was guilty but let him off because he did not have proof that would stand up in a court of law. ${ }^{118}$ As a result, the proceedings have been called "the greatest whitewash in the history of baseball."119

Giants' manager, John McGraw, signed Chase for the 1919 season when no other team wanted him. ${ }^{120}$ Ironically, on the very day that Chase signed his 1919 contract, Christy Mathewson, Chase's main accuser, joined the Giants as coach and assistant manager. ${ }^{121}$ Chase played regularly for the Giants through August, until he sprained his wrist. ${ }^{122}$ His appearances after that were limited to occasional pinch-hitting roles. In September 1919, he allegedly offered pitcher Benny Kauff $\$ 500$ to throw a game in St. Louis. ${ }^{123}$ At the end of the season, the team announced that Chase and third baseman, Heinie Zimmerman,

114 Id.

115 Id.

$116 I d$.

117 Id. at 91-92.

118 See Koноuт, supra note 26, at 210.

119 Ginsburg, supra note 5, at 92.

120 Id. at 93.

121 Id.

122 Koноuт, supra note 26, at 240.

123 Id. 
had retired from baseball. ${ }^{124}$ It was later learned that the two players, along with Chicago infielder, Lee Magee, were run out of the game for their crooked play. ${ }^{125}$ McGraw explained, "I got rid of Chase and Zimmerman, even though I knew it would seriously injure my team, because I didn't want such men on the club." 126

This was the backdrop for the 1919 World Series, played between two of Hal Chase's former teams, the Reds and the White Sox. The 1919 White Sox team is still known today as the "Black Sox" because Chicago threw the Series to the Reds. ${ }^{127}$ Early efforts to reconstruct the scheme placed Chase in a leading role.

According to the story as it broke in the Chicago Tribune on September 25, 1920, Chase approached a former featherweight boxer, Abe Attell, a few weeks before the end of the 1919 season. ${ }^{128}$ Chase asked Attell whether he could find backers willing to put up $\$ 100,000$ to fix the World Series. ${ }^{129}$ Attell was a lieutenant for Arnold Rothstein who ran a casino on West Forty-Sixth Street in New York. ${ }^{130}$ Among those who worked for Rothstein were Charles "Lucky" Luciano, Meyer Lansky, Frank Costello, Legs Diamond, Waxey Gordon, and Dutch Schultz, all of whom went on to have notable careers in organized crime. ${ }^{131}$ "Chase then met with two members of the White Sox, most likely Chick Gandil and Swede Risberg, to confirm the scheme."132

Having set it all up, Chase then cashed in on it by betting against the White Sox. ${ }^{133}$ Giants' pitcher Rube Benton testified to a grand jury that Chase had received advance information about the fix and that "The Prince" had won over $\$ 40,000$ betting on Cincinnati. ${ }^{134} \mathrm{He}$ also testified that Chase had offered him $\$ 700$ to throw a game to the Cubs in September. ${ }^{135}$ Anna Chase (who was in the process of divorcing Hal) testified that she had asked him about the Black Sox fix, and he had told her, "I knew of it, and I did what I could to help it along." ${ }^{136}$ On April 25, 1922, Chase was arrested as he left a theater in San Jose. ${ }^{137}$

124 Ginsburg, supra note 5, at 93. Zimmerman went on to become a partner of the infamous gangster Dutch Schultz in a speakeasy. $I d$. at 96.

125 Koноuт, supra note 26, at 240.

126 Id.

127 Robertson, supra note 8, at 32.

128 Id.

129 Koноuт, supra note 26, at 241. Apparently, Attell and many others were aware of the disenchantment that affected many White Sox players. The source of this ill-feeling stemmed from the fact that although Comiskey had the most talented team in baseball, he paid them quite poorly in comparison to other teams in the AL. Robertson, supra note 8 , at 35.

130 Kohout, supra note 26, at 241.

131 Id. at 28.

$132 I d$. at 241.

133 Id.

134 Ginsburg, supra note 5, at 96.

135 Koноuт, supra note 26, at 238.

136 Id. at 244; see also Robert C. Hoie, The Hal Chase Case, SABR, http:// research.sabr.org/journals/hal-chase-case (last visited Nov. 1, 2011).

137 Kohout, supra note 26 at 238. 
Although he was indicted by two separate grand juries, Chase did not stand trial for the criminal charges, nor was he made one of the notorious "eight men out." 138 Judge Kenesaw Mountain Landis officially took office as the sole commissioner of baseball in November 1921, and won a reputation for his fierce and automatic determination to rid the game of scandal by banning eight members of the White Sox from baseball for life, even though a Chicago jury had acquitted them. ${ }^{139}$ While curious that Landis never publicly took action against Chase, as he did against Shoeless Joe Jackson and others, it may simply indicate that Chase's career in the major leagues was already at an end. ${ }^{140}$ Some writers have also speculated that Landis let Chase slide to bolster public

138 Robertson, supra note 8, at 37. "Eight men out" is a reference to the eight players from the 1919 White Sox team that were banished from baseball.

139 His successor, however, questioned Landis's reputation. Commissioner Happy Chandler later said that Landis was:

mostly a myth. . After the Black Sox scandal of 1919, Landis was hired to look mean, and he played the part. He didn't go to many ballgames, but when he did, cameramen always caught him in the same posture, his fist under his chin, his white hair ruffled and flying, his face a deep scowl. I don't know what he saw at a game because I'm not sure he knew much about it. He might have been sitting there just puzzling.

Kevin Nelson, Baseball's Greatest Insults: A Humorous Collection of the Game's Most Outrageous, Abusive and Irreverent Remarks 111 (1984).

140 Shoeless Joe Jackson is also on baseball's ineligible list. His career statistics, including a lifetime .356 batting average, the third highest of all time, would certainly justify placement in the Hall of Fame, but like Rose he was barred due to his association with gamblers. Jackson played on the 1919 Chicago White Sox team that lost the World Series to the heavy underdog Cincinnati Reds.

When Judge Kenesaw Mountain Landis, the first commissioner of baseball, determined that Jackson and seven other players had accepted bribes to throw the series (despite an acquittal by a Chicago jury), they were forever barred from baseball and the 1919 team became known as the Chicago "Black Sox." See generally RoBerTson, supra note 8, at 3238.

Jackson's supporters point out that he hit the only home run of the 1919 World Series, fielded flawlessly, and batted .375. See, e.g., Donald Gropman, Say It Ain't So, Joe!: The Story of Shoeless Joe Jackson (1979). Some also argue that being aware that the fix was in, Jackson asked to sit out prior to the first game, but manager Kid Gleason was stunned by the request and refused to let him. It seems likely, however, that Jackson's absence from the field of play would have suited the gamblers just fine. Moreover, Jackson's performance is not above all scrutiny.

If it is assumed that the White Sox did not attempt to "throw" the games that they won, we must eliminate from consideration games three, six and seven. See ZuMstEG, supra note 7, at 182-205 (game by game breakdown). In those games, Jackson was six for eleven. Moreover, several accounts have it that the gamblers were slow in coming across with the money, so that by the end of the series (perhaps as early as game six, certainly by game eight) many of the Sox were no longer trying to throw the games. Jackson was six for thirteen in the final three games. We might also exclude from consideration game two, which the Sox seem to have been attempting to win, probably to keep the action going for the gamblers. The Sox had more hits (10-4) and fewer errors (2-1) than the Reds in that game, but the Reds won 4-2. Jackson was three for four in that game. That leaves the first, fourth and fifth games as the ones that most likely were thrown. Jackson was only one for twelve in those three crucial games. The one hit was a double to short center field that came in the second inning of game four, with no one on base, and Jackson did not score. Although he was not charged with any errors, in both the fourth and the fifth game, Jackson made throws to the plate that failed to get a scoring runner out. Certainly these facts do not prove that Jackson attempted to lose games one, four, or five, but they tend to diminish the commonly 
confidence in baseball by pretending that the Black Sox were the only criminal element in a sport that was otherwise clean. ${ }^{141}$

On the other hand, Chase's good friend Joe Gedeon, second baseman for the St. Louis Browns and a one-time Yankee, was not so lucky. Landis expelled him for "guilty knowledge" of the Black Sox fix. ${ }^{142}$ Gedeon blamed previous lax treatment of Prince Hal to explain his own transgressions. "[I]f Chase had been punished, it would have put the fear of God into me. I would have realized what I was doing." 143

Following the Black Sox scandal, Chase continued to find work in the minors and the semi-pro leagues, primarily in California, Arizona, and Mexico. He played baseball into his fifties, though some leagues barred him. From his deathbed in 1947, Chase admitted knowing about the 1919 Black Sox scandal in advance, but denied making any money on it. ${ }^{144} \mathrm{He}$ expressed regret at the way his career turned out, "You will note that I am not in the Hall of Fame," he said, "I am an outcast and I haven't a good name. I'm the loser, just like all gamblers are. ... I'd give anything to start over." 145

Perhaps the most fitting epitaph for Chase was provided by The Sporting News in an editorial after his death: "Let us try to forget about Hal's absence from Cooperstown and remember that he was a king in his time, and in the bright annals of diamond technique, still is a monarch sans reproach." 146

asserted argument that Jackson's performance was completely above question. See RoBERTson, supra note 8, at 36-37.

141 Ginsburg, supra note 5, at 94-95. His decision not to sanction Chase is mentioned as one reason for his inclusion in the book, The Baseball Hall of Shame. Bruce NASH \& Allan Zullo, The Baseball Hall of Shame 70 (1985).

142 Ginsburg, supra note 5, at 118. White Sox player Swede Risberg had wired Gedeon and advised him of the fix, and asked him to place bets on the Reds for the both of them. Id.

143 Koноuт, supra note 26, at 210. Later, baseball player Lenny Dykstra said that the expulsion of Pete Rose from baseball caused him to give up gambling. See Ronald J. Rychlak, Pete Rose, Bart Giamatti, and the Dowd Report, 68 Miss. L.J. 889, 901 (1999). Unfortunately, Dykstra was later charged with nearly two dozen counts of fraud, grand theft and drug possession. Richard Winton, Lenny Dykstra Charged with Fraud, Theft, Possession of Cocaine and Ecstasy, L.A. Times, June 6, 2011, http://latimesblogs.latimes.com/lanow/ 2011/06/lenny-dykstra-charged-with-fraud-theft-drug-possession.html.

144 GinsBurg, supra note 5, at 97 (explaining how Chase admitted that he had knowledge the 1919 World Series was fixed, but denied any involvement and how Chase also admitted to betting on games in which he played, but claimed that he never bet against his own team). 145 Jim Johnson, Heroes and Villains: Santa Cruz County Produced Baseball Stars and Baseball Scandals, SANTA CRuz PuB. LiBr., http://www.santacruzpl.org/history/articles/ 209/ (last visited Dec. 27, 2011). Chase has also been quoted explaining his gambling:

I wasn't satisfied with what the club owners paid me. Like others, I had to have a bet on the side and we used to bet with the other team and the gamblers who sat in the boxes. It was easy to get a bet. Sometimes collections were hard to make. Players would pass out IOUs and often be in debt for their entire salaries. That wasn't a healthy condition. Once the evil started there was no stopping it, and club owners were not strong enough to cope with the evil.

New York Yankees Captains, SQuidoo, http://www.squidoo.com/New-York-YankeeCaptains (last visited Nov. 1, 2011).

146 GinsBurg, supra note 5, at 99. 


\section{Carl Mays: The Betting, Not the Beaning}

Yankee owners, Farrell and Devery, sold the team in 1915 to "the two colonels" - Colonel Jacob Ruppert and Colonel Tillinghast Huston. ${ }^{147}$ These owners did not have open ties to gambling, but one of their pitchers, Carl Mays, may have missed his opportunity for the Hall of Fame due to a gamblingrelated scandal.

Mays was born in 1891 in Liberty, Kentucky. ${ }^{148}$ He broke into the major leagues as a pitcher with Boston, teaming with Babe Ruth, Ernie Shore, and Dutch Leonard to form one of the best pitching staffs in the AL. ${ }^{149}$ The Red Sox won the World Series in 1912, 1915, 1916, and 1918. ${ }^{150}$ Mays played a big part in the club's success between 1916 and 1918, averaging more than twenty wins per year during that stretch. ${ }^{151}$ His best year was 1917 , when he turned in a record of twenty-two wins and seven losses with a 1.74 earned-run average. ${ }^{152}$ In 1918, he led the American League in complete games with thirty wins and recorded a league-high eight shutouts. ${ }^{153}$ Unfortunately, he was very emotional, which impacted his play and his relationship with others on the team. ${ }^{154}$ In 1919, he (like future Yankee teammate Babe Ruth) held out for a bigger contract. ${ }^{155}$

Both Mays and Ruth eventually signed, but many of the other star players from the championship teams were sold off to other teams. As such, the Red Sox were not nearly as good as they had been in previous seasons. During a game in Chicago on July 13, 1919, Mays lost patience with the sloppy play of his teammates and stormed off the field after two innings. ${ }^{156}$ Mays told his manager, future Hall of Famer Ed Barrow, "I'm through with this ball club; I'll never pitch another game for the Red Sox." 157 At first, it was thought that Mays would calm down and come back to the team, but he did not. Mays was eventually suspended by AL President, Ban Johnson. ${ }^{158}$

While Mays was still under suspension, Red Sox owner, Harry Frazee, the man who would soon sell Babe Ruth to the Yankees, sold Mays to the New York club. ${ }^{159}$ AL President Johnson refused to approve the deal, but the

147 John Tullius, I'd Rather be a Yankee: An Oral History of America's Most Loved and Most Hated Baseball Team 15 (1986).

148 The Baseball Encyclopedia, supra note 69, at 2195.

149 Id. at 292, 2195.

$150 I d$. at 2851, 2854, 2855, 2857.

151 Id. at 2195.

152 Id.

153 Id.

154 Ginsburg, supra note 5, at 169. Mays had the reputation of being an inconsistent player, especially if his teammates behind him committed errors during his outings. He was known to be very demanding of his fellow players, and prone to "fits of rage" whenever things didn't go his way. $I d$.

155 Kerry Keene, "The Transaction: Sale of the Century:" From the Babe in Red Stocking, in Mike Robbins, The Yankees vs. Red Sox Reader 32 (Mike Robbins, ed. 2005).

156 GinsBurg, supra note 5, at 169.

157 Id.

158 See Am. League Baseball Club of N.Y. v. Johnson, 179 N.Y.S. 498, 501 (N.Y.S.1919).

159 The Baseball Encyclopedia, supra note 69, at 2635. 
Yankees took the matter to court. The Yankees were successful, and Mays was allowed to join the club on August 2, 1919. ${ }^{160}$

In 1920, Mays was on his way to a fine season with the Yankees when tragedy struck. On August 16, 1920, the Cleveland Indians were visiting New York in a battle for first place. Cleveland shortstop Ray Chapman led off the fifth inning. He had a habit of crowding the plate and laying down bunts for base hits. As Mays delivered his first pitch with his unique "submarine" motion, Chapman leaned in. ${ }^{161}$ The pitch hit Chapman on the head, and he collapsed at the plate. ${ }^{162} \mathrm{He}$ was immediately taken to a New York hospital, where he died later that night. ${ }^{163}$ Chapman was the first and remains the only player to be killed in a major league game. ${ }^{164}$

Despite being shaken by Chapman's death, Mays went on to win twentysix games in 1920, and the following year he led the American League with twenty-seven wins against only nine losses. Coming off this tremendous season, Mays pitched the World Series opener against the Giants, throwing a fivehit shutout to win 3-0. The Yankees also won the second game by a 3-0 score, but lost the third game 13-5. That left them with a 2-1 lead in the series. ${ }^{165}$

Mays again took the mound for the Yankees in game four. The Yankees led 1-0 going into the eighth inning, but Mays fell apart, giving up three runs on four hits in the eighth inning and another run in the ninth to hand the Giants a 4-2 victory. The key hit during the eighth inning was a triple by Emil "Irish" Meusial, which came when Mays ignored Yankee manager Miller Huggins's signal for a fastball and instead threw a slow-breaking curve. The evening after the game, a film actor, whose name was never revealed, approached sportswriter Fred Lieb with a story that Ginsburg related as follows:

The actor's tale went something like this: At the start of the eighth inning, Mrs. Mays, sitting in the grandstand, flashed a signal to Carl by wiping her face with a white handkerchief. Some persons, he said, who regarded a Giants victory in the Series as absolutely necessary for their welfare, had offered Carl a rather substantial sum of cash if in close games he would serve up enough hitable[sic] pitches to lose the game. Mrs. Mays was to be the one who, by the prearranged handkerchief signal, would advise her husband that the money had been handed over. . . .Lieb brought the story to the attention of Yankee co-owner Colonel Huston and then to Judge Landis. ${ }^{166}$

Landis had Mays followed throughout the rest of the Series, but no incriminating evidence was found against him. Mays lost two games in the Series, and

160 See Am. League Baseball Club of N.Y., 179 N.Y.S. at 501.

161 GinsBURG, supra note 5, at 170-71. Mays' unorthodox "submarine" motion differed from the delivery of traditional overhand pitchers. At times, his delivery was so low that his hand scraped the ground when he was making a pitch. Submarine pitches are thought to be harder for batters to anticipate, as the ball's location is radically different when leaving the pitcher's hand. $I d$.

$162 I d$. at 171. Chapman was initially able to stand, but upon reaching the clubhouse, he collapsed again. His death led to rule changes that ushered in the "lively ball era." Id. 163 Id.

164 Id. Though he is the only player to have ever died in a major league game, several other major league players have been killed in minor league games.

165 Id. From 1919 to 1921 , the World Series was the best five out of nine rather than today's seven-game format.

166 Id. at 171-72 (quoting Frederick Lieb, Baseball as I Have Known It (1977)). 
he won one. His ERA was an excellent 1.73 and he walked no batters in twenty-six innings. ${ }^{167}$ Since pitchers regularly lose effectiveness in the late innings, Landis decided that the charges that Mays had thrown game four were unfounded. ${ }^{168}$ A couple of years later, however, Lieb was on vacation with a number of baseball figures, including Colonel Huston and Dodger manager Wilbert Robinson. Lieb reported the following:

Some time in the evening, after Huston had imbibed more than a little, he turned to me and said, "Freddy, I am going to tell you the damnedest story a baseball owner has ever told a reporter." Every time he repeated this remark, Uncle Robby would shsh-sh him and say, "No, no Colonel! Don't tell him!” But Huston would return to the subject. As the rum and Coca-Cola had its effect, some of the people in the room gradually disappeared and Robby fell asleep. Only Huston, Grayson and I were left. Grayson, still consuming Coca-Cola and rum, tried to stay awake to hear the story that Huston apparently intended to tell me, but finally he too fell asleep. So I said to Huston, "Now that we're alone, what is this story you're holding back on me?"

"I wanted to tell you that some of our pitchers threw World Series games on us in both 1921 and 1922," he mumbled.

"You mean that Mays matter of the 1921 World Series?" I asked. He said, "Yes, but there were others-other times, other pitchers." By now he was almost in a stupor and stumbled off to bed.

I suppose as a good reporter I should have stuck around the next morning and press Huston for specifics - names, dates, and all that. But I didn't. Huston hadn't appeared before [a friend] and I were scheduled to leave to play golf at Sea Island, Georgia. After our game we continued north. When I next spoke with Huston alone a year or two later, he would say that he stood by what he had told me . . . ${ }^{169}$

In the end, although Mays was never inducted, his career appeared worthy of the Hall of Fame. Mays won 207 games against 126 losses and had a career earned-run average of $2.92 .{ }^{170}$ His lifetime batting average of .268 made him one of the best-hitting pitchers ever. ${ }^{171} \mathrm{He}$ went on to scout for the Indians, the A's, and the Braves. ${ }^{172}$ A survey was conducted in the early 1970s by the Society for American Baseball Research to determine which players, who were not in the Hall of Fame, were most deserving. ${ }^{173}$ Mays placed eleventh in the

167 The Baseball Encyclopedia, supra note 69, at 2195.

168 GinsBurg, supra note 5, at 172.

169 Id. at 172 (quoting Frederick Lieb, Baseball as I Have Known It (1977)). The Yankees lost all four of the completed games in that Series. Game two was suspended after the 10th inning due to darkness. Fans felt that there were at least thirty minutes left of good light, and they made their feelings known. Rather than concern about gambling, the feeling was that the outcome here was designed to get an extra day's receipts at the box office. To counter that concern, Commissioner Landis ordered that all receipts from the suspended game be turned over to military hospitals for disabled veterans. ROBERTSON, supra note 8, at 44-45. Miller Huggins, the Hall of Fame Yankee manager, discussing former ball players in need of a helping hand, said that he would always help any of his players if they needed it, with two exceptions: Carl Mays and Joe Bush. Lieb was fairly certain that Huggins's animosity towards Mays stemmed from the 1921 World Series. GinsBurg, supra note 5, at 172.

170 The Baseball Encyclopedia, supra note 69, at 2195.

171 Id.

172 Mike Shatzkin \& Jim Charlton, The Ballplayers: Baseball's Ultimate BioGRAPHICAL REFERENCE 690 (Stephen Holtje et al. eds., 1990).

173 Ginsburg, supra note 5, at 173. 
survey, and all ten of those above him are now in the Hall. ${ }^{174}$ "Mays died thinking that the Chapman beaning precluded him from entering the Hall of Fame." ${ }^{175}$ However, sportswriter and member of the Hall of Fame's Veterans Committee, Fred Lieb, said that whenever Mays came up for discussion, it was the 1921 World Series, not the Chapman beaning, that kept him from being named to the Hall of Fame. ${ }^{176}$

\section{Babe Ruth: Yankee Due to a Bet?}

It may well be that the most important gamble in Yankee history, and perhaps in the history of sports, was wagered by the owner of another team. The bets may have had nothing to do with baseball, but they were to change the history of the game forever.

From 1912 to 1918, the Boston Red Sox franchise was the best in the American League. In four of those seven years (1912, 1915, 1916, and 1918), the Sox won the World Series. Playing as the Boston Pilgrims, they had also won the very first World Series in 1903. They finished first in the AL in 1904, but the NL champions, the Giants, refused to play a World Series against the AL champs that year.

In 1917, theatrical producer Harry Frazee bought the Red Sox franchise. He kept the dynasty together for one more year, but then things fell apart. Despite being owner of the world champions, Frazee needed money. Over the next couple of years, he sold off fifteen Red Sox players, most of them to the Yankees (including Waite Hoyt, Ernie Shore, Duffy Lewis, Dutch Leonard, and Carl Mays). ${ }^{177}$ Even the Red Sox's General Manager, Ed Barrow, eventually moved to the Yankees. ${ }^{178}$ The Red Sox finished in sixth place in 1919, and things got even worse after the season ended. ${ }^{179}$

On January 3, 1920, in the most significant transaction in baseball history, Frazee sold Babe Ruth's contract to the New York Yankees. ${ }^{180}$ In return, the Red Sox received $\$ 125,000$ and a $\$ 300,000$ loan against the mortgage on Fenway Park. ${ }^{181}$ The oft-repeated story is that Frazee sold Ruth to finance the Broadway musical comedy No No Nanette. ${ }^{182}$ That play, however, did not hit Broadway until September 16, 1925. ${ }^{183}$ According, to some accounts, the real

174 Id.

175 Id.

176 Id.

177 Daniel R. Levitt, Ed Barrow: The Bulldog Who Built the Yankees' First DYNASTY 5-6 (2008).

178 Id.

1791919 Boston Red Sox, BASEBALL-REFERENCE.COM, http://www.baseball-reference.com/ teams/BOS/1919.shtml (last visited Nov. 2, 2012).

180 Robertson, supra note 8, at 130-31. This move got Frazee named to the Baseball Hall of Shame. Id.

181 Id.

182 Leigh Montville, The Big Bam: The Life and Times of Babe Ruth 102 (2006). This rumor has been largely debunked. There are indications however, that Frazee did in fact use the money generated from selling Ruth to finance other theatrical endeavors. Id.

183 Id. 
reason Frazee sold Ruth (and the other players) was to cover his gambling debts. ${ }^{184}$

Ruth was already a legend at that time, but primarily for his pitching. He had thrown 29 2/3 consecutive scoreless innings in the World Series from 1916 to 1918 and had broken several home run records. With the Yankees, Ruth became the greatest player ever seen, and he transformed the game. In 1920, Ruth ushered in the live-ball era by hitting a record fifty-four home runs. ${ }^{185}$ The fans flocked to see him, and that season, the Yankees became the first team to draw over one million customers. Soon the Yankees were the most dominant team in baseball. In 1923, they moved to Yankee Stadium, "The House That Ruth Built," where they remained until moving into a new Yankee Stadium (adjacent to the original location) in 2010.

As for the Red Sox, they finished dead last in nine of the next eleven years. They did not win another World Series in the twentieth century. They were said to suffer from the "Curse of the Bambino," which was not broken until the Red Sox won the World Series in 2004. Perhaps, this all traces back to some bad bets made by the owner of the Red Sox. Ironically, when the sale was made, Frazee said the Yankees were "taking a gamble" by paying so much for Ruth. ${ }^{186}$

184 See, e.g., Deadline Is Near For The Giants, S.F. Chron., Sept. 9, 1988, at A26. The Sporting News ran a piece in 1917 reporting that Frazee had bet that the First World War would be over by spring training of that year. Given the context, it may have meant that some of his business decisions were based on that assumption, but others have concluded that he literally placed such a bet. See Sean Deveney, Harry Frazee, Original Curse, http:// originalcurse1918.com/redsox/harryfrazee.html (last visited Nov. 1, 2011).

185 The so-called live-ball era (sometimes called the lively ball era) began in 1920 . That year, offensive statistics rose dramatically, and it was mistakenly attributed to a new "lively" ball. In fact, cork-centered balls had been introduced around 1910, and the construction of balls remained the same between then and 1920. In reality, the dead-ball era came to an end after the fatal beaning of Ray Chapman by Carl Mays in the 1920 season. At that time, balls were not changed until they became unusable. They would often get dark and tattered, making them hard to see and therefore hard to hid. Witnesses to the Chapman beaning said that he never moved to get out of the way of the ball and he may not have seen it. The new Commissioner of Baseball, Kenesaw Mountain Landis, instituted several new rules, including replacing balls at the first sign of wear. This resulted in a ball that was brighter and easier for a hitter to see. The other major rule change was the elimination of the spitball. See Rawlings Digest, Evolution of the Ball, Baseball Dig., July 1963, at 67, 69.

186 Dan Shaughnessy, The Curse of the Bambino 2 (2000); see Michael T. Lynch, Jr., Harry Frazee, Bank Johnson and the Feud That Nearly Destroyed the AmeriCAN League 106 (2008). Today, the Harry Frazee Award is given each year in recognition of front-office incompetence. From a monetary standpoint, however, he did not do badly. Frazee bought the World Champion Red Sox for \$400,000 in 1917 and sold the last-place team for $\$ 1.5$ million in 1923, after having pocketed a significant sum from the fire-sale of players while he owned the team. According to the newspapers of that time, few Red Sox fans were sorry to see him leave. James C. O'Leary, Contract Signed for Frazee to Sell Red Sox, Boston Globe, July 12, 1923, http://www.bostonglobe.com/sports/1923/07/12/ contract-signed-for-frazee-sell-red-sox/AbmPnllyzf82usZGUMWUaP/story.html. 


\section{Del Webb: Building More than a Dynasty}

In 1923, Colonel Ruppert bought out his partner's interest in the Yankees, and owned the team until his death. ${ }^{187}$ In 1945, Ruppert's estate sold the team to Del Webb and his two partners, Dan Topping and Larry MacPhail. ${ }^{188}$ Webb was a towering figure in the modern home-building business, probably best known for the Sun City retirement communities that opened in $1960 .{ }^{189} \mathrm{He}$ had been an aspiring major-leaguer who played in several semi-pro leagues. According to one author, he was a good pitcher and might have made it to the big leagues, but at an exhibition game at San Quentin prison in 1927, he caught typhoid fever and nearly died. ${ }^{190}$ Although he was more than six feet tall and normally weighed 200 pounds, his weight dropped to ninety-nine pounds, and he was unable to play baseball for a year. ${ }^{191}$ When he recovered, he moved to Arizona for his health and settled into the business world. ${ }^{192}$

Entering the construction business in 1928, Webb's only assets were: one concrete mixer, ten wheelbarrows, twenty shovels, and ten picks. ${ }^{193}$ By 1933, his company was a $\$ 3$ million operation. ${ }^{194}$ It continued to grow during his lifetime. He said that much of his success came from applying the rules of baseball to business. ${ }^{195}$

Webb brought a certain level of professionalism to the construction industry. For instance, rather than relying on banged-together job-site shacks made of unfinished framing lumber that most construction companies used at their work sites, Webb had portable offices, identical in color, furniture, and furnishings. ${ }^{196}$ In addition, a manual outlined procedures for all projects. ${ }^{197}$ This uniformity was much in demand in the early days of World War II, when new military facilities and war plants had to be built quickly and affordably. Webb was able to deliver. ${ }^{198}$

World War II made Webb rich, but he referred to the purchase of the Yankees as "the best deal I ever made." 199 Webb and his partners acquired the Yankees, its farm teams (a total of 450 players), Yankee Stadium, and stadiums in Newark and Kansas City for $\$ 2.8$ million. ${ }^{200}$ Using Webb's real estate

187 Sullivan, supra note 35 , at 58.

188 Id. at 77.

189 Of Sun City, former player and current announcer Bob Uecker quipped: "The average age in Sun City is deceased." Nelson, supra note 139, at 139.

190 Sullivan, supra note 35, at 80 . Webb was apparently exposed to the disease through the drinking cup of an inmate, and it had a devastating effect on his health. $I d$.

191 Id.

192 Id.

193 Id.

194 Id.

195 Del Webb Helped Establish Vegas While Making Mark on Pro Sports, Las Vegas Sun, Mar 16, 1997, http://m.lvsun.com/news/1997/mar/16/del-webb-helped-establish-vegaswhile-making-mark-/.

196 A.D. Hopkins, Man of the Years, Las Vegas Rev.-J., May 2, 1999, at 28.

197 Id.

198 Id.

199 Id.

$200 I d$. 
expertise, they promptly sold unneeded real estate for $\$ 2$ million. ${ }^{201}$ The partnership ultimately sold the club at the end of the 1964 season for $\$ 14$ million. ${ }^{202}$ Moreover, Webb put the team to good business use while he owned it. He often handed out tickets to clinch deals for construction contracts and to make friends with politicians who had pork barrel projects that might later come his way. ${ }^{203}$

About the same time that Webb bought an interest in the Yankees, he was helping to construct the first "big" Las Vegas casino hotel, The Flamingo. Webb reportedly had taken on the project as a favor to a friend. ${ }^{204}$ Before he knew it, however, he found himself bound by contract to Benjamin "Bugsy" Siegel. ${ }^{205}$ Webb, who claimed not to have known who Siegel was at first, supposedly tried to get out of the deal with the notorious underworld figure. ${ }^{206} \mathrm{He}$ later explained, however, that he could not walk away because Siegel had "a binding contract as well as a bulge under his jacket pocket."207

According to Webb, Siegel once bragged that he had personally killed twelve people. ${ }^{208}$ When another mob figure got under his skin, he told Webb: "I'm going to kill that S.O.B. too." 209 Webb's face must have reflected his shock, but Siegel reassured him: "Del, don't worry. We only kill each other." ${ }^{210}$ Later, Webb said that he never had a problem with Siegel: "Bankers, lawyers, and industrialists - never knew anyone whose word was better."211

When Siegel was murdered in Los Angeles on June 20, 1947, he still owed Webb money for the recently constructed casino. ${ }^{212}$ Webb agreed to take part ownership in the Flamingo in lieu of cash payment. ${ }^{213}$ His new partners in the casino venture included the notorious gangster Meyer Lansky, and Gus Greenbaum, a Phoenix mobster who later had his throat slit. ${ }^{214}$

Webb apparently enjoyed Las Vegas. He went on to build City Hall and two high schools. ${ }^{215}$ In the early 1960 s, shortly after he took his corporation public, he built the Sahara and Mint hotels, and again he was compensated with "points" or part ownership. ${ }^{216}$ This marked the first entry of a respected

201 Id.

202 Id.

203 Id.; Del Webb Corporation, FundING UNIVERSE, http://www.fundinguniverse.com/ company-histories/Del-Webb-Corporation-company-History.html (last visited Oct. 23, 2011); Del Webb, LAS VEGAS WIKI, http://lasvegas.wikia.com/wiki/Del_Webb (last visited Feb. 13, 2012).

204 Hopkins, supra note 196.

205 Id.; Sullivan, supra note 35, at 81.

206 Sullivan, supra note 35 , at 81.

207 Id. In 1947, Commissioner Happy Chandler suspended Dodger manager Leo Durocher for a season due to his "social" relationship with Siegel and another gangster. RoGER I. Abrams, The Dark Side of the Diamond: Gambling, Violence, Drugs, and Alcoholism in the National Pastime 58 (2007).

208 Hopkins, supra note 196.

209 Id.

210 Id.

211 Sullivan, supra note 35, at 81.

212 Id.

213 Id.

214 Id.

215 Hopkins, supra note 196.

216 Sullivan, supra note 35 , at 82. 
public company into Las Vegas. ${ }^{217}$ By the 1970 s, the corporation was the largest gaming employer in Nevada, with some 7,000 employees. ${ }^{218}$

Webb's entry into the Nevada casino industry was welcomed by the Nevada Gaming Commission, which hoped that his name would inspire other reputable businesses to come to Nevada. ${ }^{219}$ Apparently it did. Howard Hughes joined the industry, perhaps because of Webb, and the two men were instrumental in polishing the image of Las Vegas. ${ }^{220}$

Webb's connections with organized crime received a cursory review in the late 1940s by baseball commissioner Happy Chandler. ${ }^{221}$ At first, the story was that Webb was not really involved with gangsters because the builder received direct payment for these construction projects. ${ }^{222}$ Later, when the long-term Las Vegas partnerships were undeniable, Webb explained that his interest was confined to the hotel and that he had no stake in the casino. ${ }^{223}$ In the 1970s, however, journalists reviewed government documents and concluded that in addition to active ownership with mobsters in Las Vegas hotels and casinos, Webb purchased a 3,000-acre ranch near Phoenix in 1959 at an exorbitant price from Detroit mob boss, Joseph Zerilli. ${ }^{224}$ Buying land at an inflated price, of course, was a common technique of settling debts that needed to be kept off the books. ${ }^{225}$

In fairness to Webb, no evidence suggests any criminal activity or improper motives in any of his commercial or baseball ventures. His development in Sun City, Arizona, helped change America's view of retirement. He took the image of "grandma and grandpa" out of rocking chairs and put them on tennis and racquetball courts, bicycles, and softball diamonds. His legacy has added immeasurably to the quality of active retirement living. He was unanimously elected to the National Housing Hall of Fame. ${ }^{226}$

217 Hopkins, supra note 196.

218 Id.

219 Del Webb Corporation, supra note 203. ("Webb's entry into gaming was lauded by the Nevada Gaming Commission, which hoped his name would bring other reputable businessmen to Nevada. It did. Howard Hughes joined in, and the two were instrumental in polishing the image of Las Vegas."); see Jack E. Sheehan, The Players: the Men who made Las VeGAs 18 (1997).

${ }^{220}$ Hughes and Webb shared an interest in flying, and they often played golf together (along with Bing Crosby, Bob Hope, and the Goldwater brothers, Barry and Robert). Del Webb Corporation, supra note 203. In fact, Webb was one of the few associates who continued to meet face-to-face with Hughes as the eccentric billionaire grew increasingly reclusive. Editorial: The Passing of an Era, Las Vegas Rev.-J., May 3, 2001, at 6B. Hughes reportedly would call Webb, give him directions like: "Go 10 miles to a dirt road, then go five miles to the top of a sand dune, then blink your lights twice." They would then get together and talk until the early morning hours. Webb never seemed to mind the eccentricities, perhaps because Webb did more than $\$ 1$ billion worth of business with Hughes. Hopkins, supra note 196.

221 Sullivan, supra note 35 , at 81.

222 Id. at $82-83$.

223 Id. at 83.

224 Id. at $81-82$.

225 Id. at 82 .

226 RG, Del E. Webb Unanimously Elected Posthumously to National Housing Hall of Fame, Bus. Wire, Apr. 23, 1984. 
In 1964, fifteen pennants and ten world championships after they purchased the Yankees, Webb and his partners sold the team to the CBS Television Network. ${ }^{227}$ A few years later, Webb considered buying into the Chicago White Sox, but Baseball Commissioner Bowie Kuhn told Webb that he would not support Webb's bid unless Webb divested himself of his casino interests. ${ }^{228}$ Webb never got back into baseball. He died in $1974 .^{229}$

\section{THE Mick}

Mickey Mantle is recorded in history as not only one of the greatest Yankees of all time, but as one of the greatest baseball players ever. His talent for the game and boyish good looks made him a star from the very beginning. Although his career was shortened by a series of devastating injuries, Mantle accumulated a long list of impressive records. He won three MVP awards and one Triple Crown (leading the league in batting average, home runs, and runs batted in). ${ }^{230} \mathrm{He}$ contributed to twelve pennants and seven World Series titles while establishing numerous World Series records, including most home runs (18), RBIs (40), runs (42), and walks (43). ${ }^{231}$ He finished his eighteen-year career with 536 home runs and a .298 batting average. ${ }^{232}$

During his playing days in New York, Mantle was known for spending late nights on the town with his teammates, Whitey Ford and Billy Martin.233 He managed, however, to stay out of serious trouble with the commissioner's office. $^{234}$ Things became a little more difficult after he retired from baseball and needed a job.

Mantle served briefly as first base coach with the Yankees in 1970, but he did not particularly like it, nor did it pay well. "I've been offered coaching jobs," he said, "Coaches don't make a helluva lotta money. Can you imagine me making \$15,000 coaching for [Yankees manager] Billy [Martin] and him making $\$ 500,000$ ?"235 So he looked around for a public relations job, and he

227 Mark Gallagher, supra note 61, at 25; Bowie Kuhn, Hardball: The Education of A Baseball Commissioner 324 (1987).

228 Kunn, supra note 227, at 217. Kuhn also blocked Edward J. DeBartolo, Sr.'s attempt to acquire the White Sox. At least one of DeBartolo's business associates unfairly claimed that this was based on anti-Italian discrimination. See Nelson, supra note 139, at 167. In reality, Kuhn's actions were consistent with his approach to baseball and gambling. DeBartolo owned and developed three thoroughbred racetracks: Thistledown in Cleveland, Remington Park in Oklahoma City, and Louisiana Downs in Bossier City, Louisiana.

229 The Gaming Hall of Fame, UNLV Center fOR Gaming Research, http://gaming. unlv.edu/hof/2000_webb.html (last visited Nov. 2, 2012).

230 Mickey Mantle, All My Octobers: My Memories of Twelve World Series When the Yankees Ruled Baseball 61 (1994); Clayton DuVall, Grandstand Baseball PuZzles 83 (2006).

231 Mantle, supra note 230, at 4.

$232 I d$. at 206.

233 Id. at 199.

234 His carousing did, however, cause the FBI to keep a file on him. Sullivan, supra note 6 , at 82 (noting that the FBI did not keep a similar file on Del Webb, despite his ties with organized crime).

235 See Milton Richman, Today's Sport Parade, UPI Sports News, Feb. 8, 1983. 
found one with a casino. ${ }^{236}$ Unfortunately, that position took him away from baseball.

The precedent was set in 1979, when Hall of Famer Willie Mays was offered a public relations position with Bally's Park Place Hotel and Casino in Atlantic City. Mays was not directly involved in the gambling operations, but he did entertain the casino's big-spenders, usually by playing golf or dining with them. ${ }^{237}$ This created a difficult situation for Baseball Commissioner Bowie Kuhn. On one hand, Mays was one of the great stars of the game. On the other, Kuhn had already refused to support Del Webb's bid for the White Sox. He had also made Oakland A's owner Charles Finley, and three minority owners of the Atlanta Braves divest themselves of their interest in Las Vegas casinos. ${ }^{238} \mathrm{He}$ even fined former Yankee third baseman, Clete Boyer, for betting on football games. ${ }^{239}$ Kuhn said that Mays, who was working as a coach for the Mets, had to choose between working for the casino and working for the Mets. ${ }^{240}$ Mays chose the casino.

In 1983, Mantle became a director of sports promotions for the Claridge Hotel Casino City (which was owned by the late Del Webb's company), signing a one-year contract worth an estimated $\$ 100,000 .{ }^{241}$ Lee MacPhail, the AL President, spoke with Mantle a few days before he signed with the casino and told him what was in store if he took the new job. ${ }^{242}$ Mantle, who had two brothers working as pit bosses in Las Vegas casinos at the time, signed with the casino anyway. ${ }^{243}$ Kuhn then ruled that Mantle could no longer work for the Yankees. ${ }^{244}$ Kuhn had little choice.

"I was expecting it," Mantle said, "I called [Kuhn], but he wasn't in. I wanted to tell him I understood what he had to do and he shouldn't feel bad about it." 245 Not being able to participate in spring training, however, was about the only real penalty Mantle faced for taking the casino job. He did fairly little work for the Yankees at the time. "If they wanted someone to strike out, they'd call me," he joked, "It really was just public relations. I was not on the payroll. . . hardly. So I'm not gonna miss it." ${ }^{246}$ Kuhn did not prevent Mantle

236 Mantle \& Gluck, supra note 2, at 252.

237 Id.

238 Kunn, supra note 227, at 323-324.

239 ABRAMs, supra note 207, at 58. Boyer was playing for the Atlanta Braves at the time of the fine.

240 Kuhn did not bar Mays from baseball the way Pete Rose was later barred. Willie, and later Mickey Mantle, was permitted to take part in old-timer games and throw out ceremonial pitches. They were simply prohibited from working for a casino and a team. KuHN, supra note 227, at 326-27.

241 Mantle \& Gluck, supra note 2, at 253; Jim Murray, An Autobiography 71-72 (1993).

242 Mantle \& Gluck, supra note 2, at 253. MacPhail explicitly told Mantle that Kuhn did not want the game tainted by anyone working in the gaming industry, and that Mantle would be banned from baseball. Id.

243 Id.

244 Id.

245 Richman, supra note 235.

246 Id. 
or Mays from playing in old-timer games or throwing out ceremonial first pitches. $^{247}$

Mantle noted a certain irony in his situation. During most of Mantle's playing career, the late Del Webb was one of the Yankee's co-owners, and at the same time, he owned several casinos. ${ }^{248}$ Moreover, the hotel and casino that Mantle had contracted to work for was part of the Webb Corporation. ${ }^{249}$ In fact, the owner of the Yankees at that time, George Steinbrenner, also owned racehorses and had an interest in a racetrack. ${ }^{250}$

Most fans sided with Mantle and Mays. Kuhn, who was already a lameduck commissioner when he imposed the ban on Mantle, took much public criticism, but he did not back down. Mantle and Mays were not reinstated until 1986, when Kuhn's successor, Peter Ueberroth, ruled that they could return to baseball as long as they did not appear in casino advertisements. ${ }^{251}$ Later that same year, Mantle and the casino amicably ended their affiliation. ${ }^{252}$

\section{Steinbrenner: The Boss}

The late Yankee owner George Steinbrenner bought the team from CBS in 1973 and owned it until he died in $2010 .{ }^{253}$ He had made his millions as owner and chief operating officer of the Cleveland-based American Shipbuilding Company. ${ }^{254}$ Before that, he was an assistant football coach at Northwestern and Purdue. ${ }^{255}$ Early critics complained about his "football-type mentality." 256 His first venture into sports team ownership was with the Cleveland Pipers of the American Basketball League, and like former Yankee owner Harry Frazee, he invested in several Broadway plays. ${ }^{257}$

247 KuHn, supra note 227, at 330. Mantle, rather unfairly, suggested otherwise after Commissioner Ueberroth lifted the sanctions.

$248 I d$. at 324.

249 Mantle \& Gluck, supra note 2, at 253.

250 Kunn, supra note 227, at 327.

251 Mantle \& Gluck, supra note 2, at 256 (this caused cancellation of a billboard that was to feature Mantle promoting the casino).

252 Id.

253 Maury Allen, All Roads Lead to October: Boss Steinbrenner’s 25-Year Reign Over the New York Yankees 4 (2000).

$254 I d$. at 2.

255 See Jack O'Connell, Record Book Could Become Murph's Turf This Year, Record, May 5, 1985 (disucssing the firing of Yogi Berra for Billy Martin: "Boss George again revealed his football mentality"); see also Nelson, supra note 139, at 32-33 ("He thinks he should have pep meetings in the clubhouse, all that Joe College crap"). First baseman Jim Spencer said: "George Steinbrenner knows nothing about baseball. He doesn't understand that this is a major league team, not Purdue." Id. at 33.

256 Robert W. Cohen, The Lean Years of the Yankees 1965-1975 153 (2004). His early approach did not lead to much success. In 1985 it was written: "Revolutions have been won with less bloodshed, human rights violations, and atrocities than that which have been inflicted on the Yankees during George Steinbrenner's reign of terror." Id.

257 See George M. Steinbrenner III, Internet Broadway Database, http://ibdb.com/ person.php?id=22055 (last visited Dec. 27, 2011). 
As owner of the Yankees, Steinbrenner's drive to win caused him to pursue free agents and new managers with vigor. ${ }^{258}$ Steinbrenner's early notoriety came from hiring and firing former Yankee shortstop turned manager, Billy Martin, five times. ${ }^{259}$ The two men even mocked the situation in a beer commercial. Steinbrenner also poked fun at himself on Saturday Night Live when he appeared in a skit criticizing bosses who fire people at will. ${ }^{260}$ Later, Steinbrenner was depicted as a friendly buffoon on the popular television series, Seinfeld. No one, however, ever doubted Steinbrenner's drive to win or his love for the team. "Owning the Yankees is like owning the Mona Lisa," he said. ${ }^{261}$

Steinbrenner's ownership of a different kind of property raised a few eyebrows over the years. He held interests in many thoroughbred racehorses. Perhaps the best known of these was Bellamy Road, who tied a thirty-two-year-old Aqueduct course record in winning the 2005 Wood Memorial by 17 1/2 lengths. ${ }^{262}$ Steinbrenner also held interests in some horse tracks, including Tampa Bay Downs in his hometown of Tampa, Florida. ${ }^{263}$

Commissioner Bowie Kuhn, who sanctioned players Willie Mays and Mickey Mantle for their association with casinos, did not impose similar sanctions on owners like Steinbrenner or Pirate owner, John Galbreath, despite significant involvement with the horses. Kuhn later explained that he felt racing was better regulated, and "baseball before my time had accepted people who were involved in thoroughbred racing, both players and owners. . . . I was encumbered by no such historical baggage with regard to casinos." ${ }^{264}$ Eventually, Kuhn "decided to close the door on the future possibility of baseball people owning racetracks," and in 1980, he put such a rule in place. ${ }^{265}$ Fortunately for Steinbrenner, he and Galbreath were "grandfathered" in, so they did not have to divest the holdings they already had. ${ }^{266}$

258 See Ronald Blum, Yankees Owner George Steinbrenner Dead at 80, WASH. TIMES, July 13, 2010, http://www.washingtontimes.com/news/2010/jul/13/yankees-owner-george-stein brenner-dead-at-80/ "For the first five years of free agency, Steinbrenner signed 10 players for about \$38 million. Steinbrenner's \$18 million, 10-year deal with Winfield was the richest free agent contract in history at the time.")

259 Allen, supra note 253, at 62.

260 See George Steinbrenner: The Actor, (July 13, 2010 8:52) http://www.myfoxdetroit .com/story/18477495/george-steinbrenner-the-actor?clienttype=printable.

261 Ira Berkow, Sports of the Times; Yankee Fans Hostages to Steinbrenner's Whims, N.Y. Times, Aug. 16, 1987, at 3.

262 Jeff Lowe, Bellamy Road First Stallion for Hurricane Hall, Thoroughbred Times, Sept. 5, 2006, http://www.thoroughbredtimes.com/breeding-news/2006/september/05/ bellamy-road-first-stallion-for-hurricane-hall.aspx. That performance made him a strong favorite in the Kentucky Derby, but he suffered an injury and finished seventh. After a failed attempt at a comeback, he was retired to stud in 2006. Id.

263 See Sports People: Horse Racing; Conviction on a Felony Won't Bar Steinbrenner, N.Y. Times, Aug. 10, 1989, at D20 (Steinbrenner's efforts to buy Canterbury Downs race track in Minnesota were almost thwarted by a felony conviction (he pled guilty in 1974 to conspiring to violate Federal election laws) that was on his record until President Ronald Reagan pardoned him in 1989. Id.; see also Steinbrenner Joins Horse Race Group, N.Y. TIMES, Feb. 10, 1993, at B16 (noting his efforts to build a track in Indiana).

264 KuHN, supra note 227, at 328.

265 Id.

$266 I d$. 
In 1981, Steinbrenner brought future Hall of Famer Dave Winfield to New York, with the richest contract in baseball history. ${ }^{267}$ The Yankees made it to the World Series that year, but Winfield had a bad post-season, and the Dodgers took the Series. ${ }^{268}$ Winfield went on to have several great years with the Yankees, but he and Steinbrenner butted heads over contractual matters - especially a cost-of-living clause that Steinbrenner felt had been slipped into the contract by Winfield's lawyers. ${ }^{269}$ In 1984, Steinbrenner tried to trade Winfield to the Texas Rangers, but Winfield (who ended up having a great year) vetoed it. ${ }^{270}$ Steinbrenner never forgot that. Ultimately the two men stopped talking to one another.

In the late 1980s, a dispute arose over a contractual provision that called for the Yankees to make payments to Winfield's charitable organization. ${ }^{271}$ Winfield said that payments had not been made, and Steinbrenner countered that the charity was corrupt. Although a subsequent investigation of the charity by the Commissioner's office was dropped due to the lack of credible evidence, the investigation revealed that Steinbrenner had paid $\$ 40,000$ to a small-time gambler named Howard Spira. ${ }^{272}$

Spira was a convicted gambler and tax cheat who surfaced one day around the Yankee clubhouse. No one knew who he was or what he did. Somehow he had credentials and would be allowed into the Yankee clubhouseFalse He sat in the Yankees dugout, ate in the press room. . . worked his way upstairs to the press level, talked rapidly, and he hung on. He was a professional hanger-on. ${ }^{273}$

The speculation in baseball circles was that Steinbrenner had hired Spira to dig up some dirt on Winfield. ${ }^{274}$

Commissioner Fay Vincent hired prosecutor John Dowd (who is best known as the author of the "Dowd Report" - Baseball's report on Pete Rose's gambling activities $)^{275}$ to investigate. This resulted in a disciplinary hearing. Vincent found Steinbrenner's conduct to be contrary to the best interests of baseball, fined Steinbrenner, and forced him to resign as general partner of the Yankees in $1990 .{ }^{276}$ Steinbrenner signed a statement agreeing not to challenge

267 Nemec, Baseball Chronicle, supra note 22, at 493.

268 Allen, supra note 253, at 160.

269 Id. at 153.

270 Id. Ironically, 1984 was the year that Winfield was to be outdone by his teammate Don Mattingly, who outdid Winfield's gaudy .340 batting average with his own .343 average. Id. 271 Id.

272 See Jill Lieber \& Craig Neff, Bad Job, Baseball, Sports Illustrated, Oct. 8, 1990, at 34.

273 Allen, supra note 253, at 154.

274 Id. (discussing how Steinbrenner reportedly paid Spira $\$ 40,000$ to try and blackmail Winfield and how these actions would earn Steinbrenner one of his multiple suspensions from baseball).

275 See Rychlak, supra note 1, at 893, 903 (introduction to the Dowd Report; the report itself is printed in full thereafter).

276 See Murray Chass, Steinbrenner's Control of Yanks Severed, N.Y. Times, July 31, 1990, at A1; see generally Lieber \& Neff, supra, note 272, at 34; see Decision on Steinbrenner; A Finding Based on 2 Key Premises, N.Y. Times, July 31, 1990, at B8. 
Vincent's actions or the disciplinary hearing in court. ${ }^{277}$ In 1993, Commissioner Bud Selig reinstated Steinbrenner. ${ }^{278}$ After that, Steinbrenner's Yankees reemerged as the dominant team in the major leagues, winning world championships in 1996, 1998, 1999, 2000, and 2009; winning AL pennants in 2001 and 2003, AL Eastern Division titles in 2002, 2004, 2005, and 2006; and winning wild card births to the playoffs in 1995, 1997, 2007, and 2010. ${ }^{279}$ At one point along the way, they set a record with fourteen straight wins in World Series games. ${ }^{280}$

\section{REAL SPORTS}

In the summer of 2002, a story appeared in the press claiming that Yankee players had fixed some games in the 1970s and 1980s. It began with the HBO television program, Real Sports with Bryant Gumbel. One of the guests was Michael Franzese, a former capo in the Colombo crime family and head of their gambling operations. ${ }^{281}$

Franzese said that he and a partner in a Long Island car dealership initially lured professional football and baseball players with free cars, then got them involved with gambling. ${ }^{282}$ "Some sports figures ran up large gambling debts with the bookies, and as their debts mounted, the players' choices narrowed." ${ }^{283}$ Eventually, the players had no choice but to do what the mob told them. ${ }^{284}$ Sometimes that meant just providing information, other times it meant throwing a game or shaving points. "You let us know what's going on in that clubhouse," Franzese says he told the players, "You . . . know . . . who's sick, who's having a fight with their wife." ${ }^{285}$ That information, of course, gives gamblers an edge in their betting.

During the program, HBO's Bernard Goldberg named the Yankees of the 1970s and 1980s as being among the teams that were influenced by Franzese and his associates. ${ }^{286}$ The Yankees immediately responded by attacking Franzese's credibility. ${ }^{287}$ A public relations executive said: "The charges made by Franzese are absolutely beyond belief. He's a discredited former hoodlum,

277 See Maryann Hudson, Steinbrenner Lawyer Calls For Investigation; Baseball: Vincent Said To Be Running Out Of Patience With Challenges To His Authority, L.A. TIMEs, Oct. 12, 1990, at C1.

278 Pamela Skillings, George Steinbrenner - New York Owner, Авочт.Сом, http:// manhattan.about.com/od/governmentandpolitics/p/George-Steinbrenner-New-York-Yankees -Owner.htm (last visited Nov. 2012).

279 Id.

$280 I d$.

281 See Murray Chass, Baseball; Ex-Mobster Says He Influenced Yankees, N.Y. Times, July 24, 2002, at D6.

282 Russ Buettner, Ex-Gangster Says N.Y. Pro Games Fixed, N.Y. Daily News, July 23 2002, http://www.nydailynews.com/archives/news/2002/07/23/2002-07-23_ex-gangster_ says_n_y_pro_ga.html.

283 Chass, supra note 281.

284 Id.

285 Buettner, supra note 282.

286 Ron Maly, Hawkeye Past and Hawkeye Future, July 25, 2002, http://iowa.scout.com/2/ 55311.html. See Chass, supra note 276.

287 See Chass, supra note 281. 
and it's an outrage that any credence would be given to him with his bad reputation as he seeks personal publicity. The Yankees know nothing about any of these claims." 288 Yankee spokesman Rick Cerrone raged, "This doesn't even merit a comment, it's so ridiculous." ${ }^{289}$ After all, Franzese was a mob figure, and in 1986, he had been sentenced to ten years in prison on racketeering, conspiracy, and tax-fraud charges. ${ }^{290}$

Franzese has worked for Major League Baseball ("MLB") in its annual rookie career development program. His role was to lecture them on the dangers inherent in involvement with gamblers. ${ }^{291}$ The Federal Bureau of Investigation recommended Franzese to MLB, and he also worked for the National Basketball Association and the NCAA. ${ }^{292}$ In addition, he has appeared in a video produced by the four major professional leagues on gambling and other dangers players should avoid. ${ }^{293}$

Of greatest importance, however, was that in the broadcast, he did not name the Yankees or any of their players as being involved, and he denied ever having identified the Yankees. ${ }^{294}$ In fact, it was confirmed that even though he worked for MLB's security department, Franzese had never reported to his superiors that he had conspired with Yankees to fix games. ${ }^{295}$ "That's brand new," said Kevin Hallinan, baseball's senior vice president for security and facilities. "I have not heard that." 296 In a private conversation at the 2010 NCAA annual meeting (in Atlanta) where Franzese was speaking on the dangers of gambling for student athletes, Franzese said that the television program went beyond his comments when it implicated the Yankees. ${ }^{297}$

The Yankees organization and individual players from teams of that era denied these allegations. "I can't imagine us fixing anything if we were winning," Chris Chambliss, a former Yankee first baseman said. "We played to win every game. We showed it by being in the World Series three years." 298 The Yankees were the AL champions in 1976, 1977, 1978, and 1981. They won their division title in 1980, and won the World Series in 1977 and 1978.

288 Id.

289 Bill Hoffmann, Yanks Rip Mob Claim of Fixed Ballgames, N.Y. Post, July 23, 2002, at 3.

290 Id. For an account written as the story was breaking, see Ronald J. Rychlak, Unlucky Numbers: Betting On, Against, and With the Yankee\$, in Courting the Yankees: Legal Essays on the Bronx Bombers 229-30 (Ettie Ward, ed. 2003).

291 Howard Beck, A Lesson in Gambling From One Who Knows, N.Y. Times, Sept. 21, 2007, http://www.nytimes.com/2007/09/21/sports/basketball/21 gambling.html.

292 Terence Loose, Interview: Michael Franzese, CoAst, June 2008, at 40, 46, available at http://tloose.com/Michael_Franzese_Interview_PDF.pdf; Student Athlete Affairs Hosts Former Mafia Boss and Speaker Michael Franzese, Penn State Behrend Lions, Jan. 13, 2011, http://www.psblions.com/information/general_news/Guest_Speaker.

293 Loose, supra note 292. Franzese has also written and spoken of his development as a Christian. See Michael Franzese, Blood Covenant: He Quit The Mob and Lived (2003).

294 Allegations Denied: Franzese Did Not Name Any Team or Player in Interview, SI.com (July 23, 2002, 8:23 PM), http://sportsillustrated.cnn.com/baseball/news/2002/07/23/ franzese_controversy/.

295 Chass, Ex-Mobster Influences Yankees, supra note 276.

296 Id.

297 Interview with Michael Franzese, in Atlanta, Ga. (Jan. 13-16, 2010).

298 Chass, Ex-Mobster Influences Yankees, supra note 276. 
Willie Randolph a former second baseman for the Yankees and the team's third-base coach at the time these charges were made, said that if anything funny was going on, he was not aware of it: "That's so foreign to me. . I was just a young guy, really intense, just into doing my job, win or lose or go home." 299

Mickey Rivers, an outfielder for the Yankees from 1976 to 1979, was widely known as a gambler (reportedly a bad one). ${ }^{300}$ He liked horse tracks, poker, and legal casinos. ${ }^{301}$ It was even reported that he sometimes did not shag balls in spring training because he was hiding a racing form in his uniform. ${ }^{302}$ There has, however, never been any indication of illegal betting or wagering on baseball. Moreover, the Yankees made it to the World Series each of the three full seasons that Rivers spent with the Yanks. In light of the denials from everyone associated with this scandal, including Franzese, it died quickly and quietly.

\section{A-Rod: A Risky Deal}

Alexander Emmanuel "Alex" Rodriguez, popularly known as A-Rod, began his career playing shortstop with the Seattle Mariners (1994-2000), and then the Texas Rangers (2001-03). In February 2004, the Rangers traded Rodriguez to the Yankees for second baseman Alfonso Soriano and a "player to be named later." 303 After four years of all-star play with the Yankees, Rodriguez agreed to a ten-year, \$275 million contract in 2007. ${ }^{304}$ That contract was the richest in baseball history at that time. ${ }^{305}$

Rodriguez is undeniably one of the top players of all time. He is the youngest player ever to reach 500 and then 600 home runs. ${ }^{306} \mathrm{He}$ has had more $100-$ RBI seasons in his career than any other player in history. ${ }^{307}$ As of this

299 Id.

300 Bob Hertzel, Any Pastime is Fair Game, The Record, July 23, 1993.

301 Id.

302 Id.

303 Paul C. Weiler \& Gary R. Roberts, Sports and the Law: Text, Cases, Problems 310 (West 2004). Joaquín Árias was sent to the Rangers the following month. The Rangers also agreed to pay $\$ 67$ million of the $\$ 179$ million left on Rodriguez's contract, and Rodriguez agreed to switch positions from shortstop to third base (due to Yankee shortstop Derek Jeter) and to switch uniform numbers, from three to thirteen (three having been retired in honor of Babe Ruth); see New York 500 Club: Alex Rodriguez, ESPN New York, http:// sports.espn.go.com/new-york/mlb/news/story?id=5188282 (last updated Aug. 4, 2010, 1:30 PM EST).

304 Anthony DiComo, Yankees Finalize Deal with A-Rod, yANKEES.COM (Dec. 13, 2007, 1:04 PM), http://newyork.yankees.mlb.com/news/article.jsp?ymd=20071213\&content_id=23 24707.

305 Id.

306 Alex Rodriguez, ESPN MLB, http://espn.go.com/mlb/player/_/id/3115/alex-rodriguez (last visited Nov. 6, 2011).

307 Id.; New York 500 Club, supra note 303 (discussing how he was the youngest player to hit 500 home runs); Howie Rumburg, Alex Rodriguez Pulls Out Of All-Star Game, HufFINGTON Post (Jul. 8, 2011, 6:58 PM EST), http://www.huffingtonpost.com/2011/07/08/alex -rodriguez-all-star-game_n_893578.html ("Rodriguez was elected by the fans to a 14th AllStar appearance, most among active players"). 
writing, he has been named to the All-Star team fourteen times. ${ }^{308}$ Nevertheless, A-Rod's legacy is tainted. In February 2009, after previously denying use of performance-enhancing drugs, he admitted to using steroids from 2001 to 2003 , while he was playing for the Rangers. ${ }^{309}$ That alone may or may not keep him out of the Hall of Fame, ${ }^{310}$ but there are also questions about his gambling.

In 2005, the Yankees and baseball commissioner Bud Selig warned Rodriguez about gambling in underground poker clubs that were becoming popular in New York. ${ }^{311}$ They were concerned that involvement with gamblers who might be betting on baseball games could result in a lifetime ban from baseball. ${ }^{312}$ At the time, Rodriguez admitted that his participation "wasn't the right thing to do." ${ }^{313}$ Unfortunately, new reports surfaced in 2011 that Rodriguez had again been involved in high stakes poker. ${ }^{314}$

The allegations first published by RadarOnline.com and in Star magazine, were that Rodriguez played in two high stakes games in 2011 while he was on the disabled list after surgery to repair his left knee. ${ }^{315}$ One of the games allegedly took place at the Beverly Hills mansion of record executive Cody Leibel. ${ }^{316}$ At that game, a fight nearly broke out when one of the players refused to pay up after losing more than a half-million dollars. ${ }^{317}$

The other game, which A-Rod reportedly helped organize, took place in Miami. ${ }^{318}$ One gambler lost tens of thousands of dollars and called in some "muscle" to intimidate the other players and try to avoid paying his debts. ${ }^{319} \mathrm{~A}$ Rod reportedly fled the scene. ${ }^{320}$ According to the New York Post, actors Leo-

308 Alex Rodriguez, ESPN MLB, http://espn.go.com/mlb/player/_/id/3115/alex-rodriguez (last visited Nov. 6, 2011).

309 A-Rod Admits, Regrets Use of PEDs, ESPN.com, (Feb. 9, 2009), http://sports.espn.go. $\mathrm{com} / \mathrm{mlb} /$ news/story?id=3894847.

310 Mark McGwire seems to have been kept out of the Hall of Fame due to concern about his use of performance enhancing drugs, and as of this writing, no players who are known to have used steroids have been elected.

311 Starting Blocks, Alex Rodriguez May Have Taken Part in Illegal, Underground Poker Games; MLB Taking Allegation 'Very Seriously:' Report, Cleveland.com (Aug. 3, 2011, 3:10 PM), http://www.cleveland.com/ohio-sports-blog/index.ssf/2011/08/alex_rodriguez. html.

312 Wallace Matthews, MLB Investigates A-Rod Gambling, ESPN.com, (Aug. 3, 2011), http://espn.go.com/new-york/mlb/story/_/id/6830659/mlb-suspend-alex-rodriguez-new-yorkyankees-illegal-poker.

313 Id.

314 Dylan Howard, A-Rod Played In Top Secret Poker Ring Where Drugs Were Used, Say Eyewitnesses, RADARONLINE.COM (Aug. 3, 2011, 7:30 AM), http://www.radaronline.com/ exclusives/2011/08/alex-rodriguez-a-rod-played-hollywood-poker-ring-drugs-used-say-eye witnesses.

315 Id.

316 Id.

317 Id. The account reported that "cocaine was openly used" at the game. There are, however, no allegations that Rodriguez took part in using cocaine. See id.

318 Id.

319 Id.

320 Sean Gregory, A-Rod's Bad Bet: Why Great Athletes Love to Gamble, Time, Aug. 5, 2011, http://www.time.com/time/arts/article/0,8599,2087029,00.html. 
nardo DiCaprio, Ben Affleck, Matt Damon, and Tobey Maguire also were involved in one or both of these games. ${ }^{321}$

The legality of underground poker is an area of dispute. The traditional definition of gambling involves consideration, chance, and reward. ${ }^{322}$ Consideration and reward are present with poker, but the result is largely dependent upon skill, not chance. ${ }^{323}$ In fact, poker tournaments have become popular television programming, particularly on networks like ESPN that specialize in sports programming. ${ }^{324}$ The fact that the same players regularly rise to the top of these tournaments indicates that skill matters more than luck.

Private, in-home, gambling is rarely prosecuted. About half the states provide express exemptions from anti-gambling laws for in-home "friendly" poker games. ${ }^{325}$ When it is prosecuted, it is usually a misdemeanor. Thus, one commentator quipped: "as alleged transgressions go, this one doesn't even make ARod's personal top-10 list." 326

On the other hand, not every state turns a blind eye to friendly gambling. Large stakes, commercial-type games do not fall under those exemptions. In other words, the kind of game that Rodriguez is alleged to have participated in is illegal in most states. ${ }^{327}$ Of greatest importance to MLB is that professional

321 Sean Kernan, Yankees' A-Rod folds on Poker Talk, N.Y. Post, Aug. 5, 2011, http:// www.nypost.com/p/sports/yankees/rod_folds_on_poker_talk_p5pclHrayBwErz348prBxJ.

322 Boies v. Bartell, 310 P.2d. 834, 837 (Ariz. 1957); Horner v. U. S., 147 U.S. 449, 459 (1893). In addition, where state laws prohibit gambling "for profit," profiting by the deed is a necessary component of the offense, see, e.g., State v. Geddaro, 579 P.2d 949, 951 (Wash. Ct. App. 1978).

323 See Joseph M. Kelly et al., Poker and the Law: Is It a Game of Skill or Chance and Legally Does It Matter?, 11 Gaming L. Rev. 190, 190 (2007).

324 "[H]asn't ESPN made a legitimate sport of high-stakes poker already, televising matches where millions of dollars are at stake?" Tim Dahlberg, A-Rod Poker Probe Shouldn't Be His Biggest Worry, YAHOo! SPORTS, Aug. 7, 2011, http://sports.yahoo.com/mlb/news?slug=aptimdahlberg-080711.

325 Florida Statute $\S 849.01$ provides that one who owns, operates, or manages a house or room used for the purpose of gaming or gambling is guilty of a felony of the third degree, unless it is a "penny-ante game" excluded per section 849.085. Fla. Stat. § 849.01 (2010). According to $\S 849.085$, a penny-ante game is any game that:

1. Does not contain a pot of more than $\$ 10$.

2. Does not charge an admission or 'rake' by the host from its players.

3. Is conducted in somebody's home.

4. Is not advertised in advance.

5. Does not contain any player under the age of 18 .

6. Debts incurred in such a penny-ante game are not legally enforceable, nor can any participant or host of a penny-ante game be charged in court.

See Fla. Stat. § 849.085 (2010). Clearly, if the allegations are true, the Florida game that Rodriguez attended and/or organized does not fall within the "penny-ante" exception.

326 Dahlberg, supra note 324.

327 The California Gambling Control Act, section 19801(c), states: "Gambling can become addictive and is not an activity to be promoted or legitimized as entertainment for children and families." CAL. Bus. \& Prof. Code $§ 19801$ (c) (2011), available at http://ag.ca.gov/ gambling/pdfs/gambling_law_2011.pdf. Subsection (d) provides: "Accordingly, no person in this state has a right to operate a gambling enterprise except as may be expressly permitted by the laws of this state and by the ordinances of local governmental bodies." Id. $\S 19801(d)$. In other words, to be legal, gambling must be licensed by the state. The logical conclusion would be that an "underground poker club" would be illegal. But see Julia Felsenthal, A-Rod's Poker Game Is Illegal. Is Mine, Too?, Slate, Aug. 4, 2011, http:// 
gamblers tend to be around these high-stakes games, and it is unwise for professional (or collegiate) athletes to be associated with such individuals. ${ }^{328}$ It is even worse to risk the possibility of becoming deeply in debt to professional gamblers. For this reason, MLB had to investigate the allegations about Rodriguez. "We're talking to people involved in the investigation, and we're taking this very seriously," said one MLB executive on the condition of anonymity. "Because he had been warned about this before, I would say a possible suspension would be very much in play." 329

Rodriguez's spokesman, Richard Rubenstein, said that the story being reported "contains numerous factual inaccuracies and Alex looks forward to cooperating with MLB in their investigation." ${ }^{330}$ A witness has also come forward to state that he was at one of these poker games and A-Rod was not there. ${ }^{331}$ Moreover, some reports from MLB say that Rodriquez may not face a suspension regardless of the outcome of the investigation. ${ }^{332}$ Both legally, and contractually, this is a complicated issue. Certainly Yankee fans want to see ARod on the field, not on the sidelines, but the potential problems facing him due to his alleged involvement in a couple of poker games is a reflection of the long and complicated relationship between baseball and betting. It is a relationship that is certain to continue.

\section{Conclusion}

Like most sports, baseball has had its share of scandals, including those associated with gambling. Of course, just about anything in baseball history can be found in the history of the New York Yankees; gambling and scandal are not exceptions. One lesson to take from history is that it repeats itself. There are certain to be more gambling-related stories involving baseball in the future, and some of them undoubtedly will involve the New York Yankees. The specific events are impossible to anticipate, but important to address once they happen.

Major League Baseball has done a good job in keeping the game clean, both by providing guidance to young players and by taking a hard line against

www.slate.com/articles/news_and_politics/explainer/2011/08/arods_poker_game_is_illegal. $\mathrm{html}$ (arguing that poker is legal under California law). Not only is Major League Baseball investigating the allegations against Rodriguez, the FBI is also reportedly looking into them. Nancy Dillon et al., MLB Investigating Alex Rodriguez's Reported Involvement in HighStakes, Illegal Poker Games, DAILy News, Aug 3, 2011, http://articles.nydailynews.com/ 2011-08-03/sports/29870057_1_mlb-investigators-underground-poker-star-magazine.

328 See generally Kelly et al., supra note 323, at 196. It is not uncommon for experienced players to exploit less skilled players in high stakes games.

329 Matthews, supra note 312.

330 Id.

331 Dillon et al., supra note 327. Dan Bilzerian, a named source in the original story, said "It's ridiculous. ... He wasn't there, I'm telling you. He was playing in the World Series at the time." Id. But another unnamed source said Rodriguez attended at least one game on the same circuit. Teri Thompson et al., Alex Rodriguez Has Attended Illegal Poker Games, But Not One Named in Reports, Source Says, Daity News, Aug 5, 2011, http://articles.nydaily news.com/2011-08-05/sports/29870051_1_underground-poker-illegal-poker-source.

332 Todd Venezia, MLB Won't Ban A-Rod Over Poker Claims: Source, N.Y. Post, Aug. 7, 2011, http://www.nypost.com/p/sports/yankees/rod_safe_call_ERzUG0eMcd6NGjGV4Gap

$7 \mathrm{~K}$. 
all gambling on baseball. ${ }^{333}$ The Yankees have also taken steps by warning players about developing gambling issues and by having special agents mingle with the fans at the park, trying to uncover illegal gambling. ${ }^{334}$ Strict rules, of course, can lead to harsh judgments, ${ }^{335}$ but that is necessary if Major League Baseball and the Yankees are to preserve their good names and not regress to the corruption that permeated the game in the nineteenth century.

Today, more than ever, Major League Baseball needs to be particularly attentive. Gambling is present throughout our society, and ball players are not immune to its appeal. Moreover, as modern America has embraced many forms of gambling, it has become harder to enforce prohibitions. ${ }^{336}$ Players who gamble, however, do not only jeopardize their careers, they present a real threat to the game. As such, the league and individual teams like the Yankees need to be vigilant.

One day, unfortunately, there will be another significant gambling-related scandal in Major League Baseball. Until then, keep the focus on the field, where the New York Yankees remain a good bet day in and day out. ${ }^{337}$

333 See Major League Baseball Rule 21(d), which is posted in all major and minor-league clubhouses, came into effect in the 1920s, after the Black Sox scandal. It provides:

Any player, umpire, or club official or employee, who shall bet any sum whatsoever upon any baseball game in connection with which the bettor has no duty to perform shall be declared ineligible for one year.

Any player, umpire, or club or league official or employee, who shall bet any sum whatsoever on any baseball game in connection with which the bettor has a duty to perform shall be declared permanently ineligible.

Major League Rule 21, SeAn LAHMAn, http://baseball1.com/files/rose/rule21.html (last visited Oct. 28, 2011). Major League Baseball also has speakers address gambling at its annual rookie career development program. Howard Beck, A Lesson in Gambling From One Who Knows, N.Y. TIMES (Sept. 21, 2007), http://www.nytimes.com/2007/09/21/sports/basket ball/21 gambling.html.

334 Abrams, supra note 192, at 59.

335 Baseball's all-time hit leader, Pete Rose, has been permanently suspended from the game (and thereby denied entrance into the Baseball Hall of Fame) because he bet on the game. See Rychlak, supra note 1.

336 See George Vecsey, Stan Musial: An American Life 21 (2011) (nothing that when baseball fans elected Pete Rose to the all-centuty team in 1999, it may have indicated that they did not see gambling as a particularly bad thing).

337 In The Cheater's Guide to Baseball, author Derek Zumsteg outlines several fun betting games for baseball fans. One of them, named after the perennial all-star Yankee shortstop, is called "Past a Diving Derek Jeter." In no way, however, does the game implicate Jeter or any other baseball player in gambling activity. ZuMSTEG, supra note 7, at 174. 